\title{
In Bad Shape: Sensing the Criminal Corpse
}

The recreation of the gallows scene in the Georgian era by leading crime historians has been deservedly praised for its authentic contemporary picture of eighteenth-century executions. ${ }^{1}$ The stimulus for doing this original research was, Vic Gatrell remarked, that 'death by execution may be one of the last agreed obscenities' in modern times but that 'taboo has not served history well'. ${ }^{2}$ It was a material reality that 'what the noose really did to people' challenged eighteenth-century sensibilities. Remaining shielded from this physical reality is hence not an option if this book is to retrace all the anatomical things that could potentially happen under the Murder Act. Gatrell's work has now established that on the hanging-tree 'the dead body never failed to betray the nature of its experience however scientifically despatched'. ${ }^{3}$ Penal surgeons generally observed four physical traits. It was obvious that it took time to die, and this varied a lot. On arrival at the gallows the typical behaviour of the condemned was described as a combination of convulsive shaking and audible distress, with many paralysed by fear, often fainting. Then, as the convicted murderer climbed the scaffold steps, or were hoisted up, the panic they experienced started to complicate the executioner's course of action. Few prisoners could avoid producing a sharp adrenalin rise, sweating profusely, making it more difficult for the hangman to handle condemned bodies. Historically a hormonal trigger known as a classic 'fight or flight mechanism' stimulated some criminals to try to resist execution, others felt compelled to 
escape, and the remainder were rigid with trepidation. ${ }^{4}$ Some variant of this involuntary hyper-arousal mechanism was thus inescapable. Normal biological continuities were repeatedly experienced. It followed that a third observation that was commonplace was the awful sense of anticipation caused by an acute stress response. Feeling scared stiff tended to be mentally as terrifying as the physical pain of punishment. In many cases, finally, foul-smelling excrement expelled down the lower limbs as the stimuli of the autonomic nervous system were activated. ${ }^{5}$ Reflexive actions like urine incontinence were routine. A lot of condemned bodies were accordingly in a 'bad shape' in the supply chain by the time they reached a criminal dissection location.

When peri-mortem (at, or near the point of death) the hangman sometimes had to use rougher killing methods to despatch strong-necked murderers. If so, the so-called corpse handed over to the surgeons tended to be more damaged, complicating the working duties of medico-legal officials. Hence, this chapter is all about the sensory nature of execution spectatorship when in a 'bad shape' and 'dying by degrees' (a medical concept introduced in Chapter 2). Everyone present played some part in a stimulating synaesthesia since the physical showcase assaulted the five senses. A nauseous bodily drama, and the immersive theatre of its punishment tragedy, refashioned the 'curious' personality of the early modern crowd too. This context explains why Paul Barber in his studies of eighteenth-century medicine and society has found that the early modern body between life and death has always been visually arresting: 'It can stiffen and relax, bleed at the mouth and nose, grow, shrivel, change colour with dazzling versatility, shed its skin and nails, appear to grow a beard, and even burst open'. ${ }^{6}$ All of these physical traits were exacerbated by the execution process. They equally exaggerated what the condemned looked like to the duty penal surgeon post-execution. Yet, seldom have the punishments done to the executed body been considered in-tandem. This chapter is therefore going to retrace their physical relationship at their metabolic connection, known forensically as peri-mortem. It analyses the strong symbiosis that there was between the material condition of the body executioners knew and those anatomists actually handled.

If the 'bad body' had been treated clumsily, was diseased by contagious smallpox, or very dirty from being covered in body-lice spreading typhus, then it was unlikely that it would spend a lot of time in a chosen dissection space. This was for the simple reason that it might contaminate the community. The 'good body' by contrast was usually despatched efficiently, 
did not have dysentery of the bowels, or contain 'bad blood' to taint the penal surgeon on duty. Those that nicked their hands with the lancet were aware of the risk of fatal blood-poisoning (see, also Chapter 6). In many respects, then, the precarious nature of doing general dissection work, which is documented in broad terms by the historical literature, nevertheless remains poorly understood as a penal set of hazards. ${ }^{7}$ More needs to be known in crime studies with regard to how the condemned taken from the gallows when peri-mortem actually affected the penal circumstances of criminal dissections. Hence, the medical triage of gallows bodies was not done to save lives on the hanging-tree, but to protect surgeons and the crowd from the condemned in a 'bad shape' awaiting post-mortem 'harm' in early modern England under the Murder Act. ${ }^{8}$

Section 1 of this chapter begins by exploring the basic medical problems that the execution process created for penal surgeons and the opportunity costs they presented in terms of a physical set of punishment constraints. Of relevance is: the efficiency (or not) of the short/long drop; the calculation (or lack of it) of body weight to rope length; the careful selection (or clumsy choice) of knot and where to place it around the neck; as well as, the regional customs that endured which were not necessarily medically proficient at the provincial hanging-tree. Above all, it will be shown that historians of crime and medicine need to re-examine what happened physically to the condemned body at two critical metabolic momentsjust before-and just after-it stopped shaking on the rope. In this transitional peri-mortem phase of punishment certain metabolic processes were commonplace because everyone dies in the same way when put through a traumatic death by a broken neck or strangulation with a rope. These physical characteristics are closely examined since their medical attributes can be identified with some precision despite their historical distance. On arrival at dissection venues, observations were made about what normal symptoms looked like when someone was in capital death (as we saw in Chapter 2). Contemporary accounts of death and dying likewise featured in local newspapers and were retold by ballads-sellers. These sources, used sensitively by carefully sifting sensationalised cases sold to a popular market, can enable researchers to side-step the historical snare of retrospective diagnosis. The external and internal metabolic drama always betrayed itself on the blackened skin, swollen eyes, bruised face, or blood-patched hands, feet, limbs, and so on. Contemporaries thus came to recognise the liminal medical processes of capital death. Accumulating a material knowledge enabled most to learn something about better ways to die on the gallows 
than others. There was a dreadful, painful side to the procedures when the criminal fought their fate and prolonged the agony. For spectators and perpetrators alike, it was a physical showcase of slippages - in blood, sweat and tears, as well as urine, excreta and semen-even before the lancet was lifted. All of this medical purging recast the condition of the criminal as it became a corpse for public consumption.

In follows that in Sections 2 and 3, this chapter examines several prominent trial narratives and their medical circumstances to illustrate what happened in hanging-towns that dealt with headline-making homicide cases. In the first case we encounter what it meant to kill someone and then be convicted to die by an equivalent set of painful penalties. In the second trial two dangerous men that murdered callously became the public property of penal surgeons, featuring prominently in contemporary publications. These, and associated record linkage work, together reconstruct what contemporaries had an opportunity to see from a medical standpoint once the condemned had been hanged and was about to be handed on. Such scenarios show-case what became known as the 'dangerous dead'; on delivery to the surgeons these were simultaneously ordered/disordered, attractive/repellent, and mundane/unnerving. In some areas of the country we have no more than a hint of the fusion of these binary ambiguities, whereas in other places they are well-documented.

A rich seam of archival research from Nottingham Assizes is then utilised as an historical prism in Section 4 to compare common body types and their medical conditions. Those delivered for dissection in the heartland of the East Midlands set medico-legal standards for many provincial English towns. Sampling local records introduces a representative selection of criminal bodies that were termed 'dirty', 'diseased', or 'contaminated', as well as the 'good' and 'extras'.' All of this human material was said to be 'in limbo', a notion that reflected confusion surrounding the spiritual beliefs and medical sensibilities of the early modern crowd. Since murderers typically shared a history of violence, the equivalent force marked on their bodies left many badly damaged during the execution process itself. This ironically added to the powerfully disturbing bodily sense of criminal potency, even before being supplied for dissection. In so doing when images of the criminal corpse were created by contemporary artists they were often caricatured to try to capture with satire the extent to which execution from a medical standpoint was disturbing in the long eighteenth-century. In the chapter's final Section 5, therefore, several of the most iconic images featuring renowned characters condemned to 
die that were once famously sketched by William Hogarth and Thomas Rowlandson are re-appraised. Re-examining notorious criminal corpses reveals a surprising set of medico-legal perspectives that call into question certain art historical clichés. The overall intention in this chapter is then to envisage medical men waiting to get hold of the peri-mortem body, to grasp the next step on a highly symbolic punishment journey.

\section{The Condition of the Criminal Corpse: Concessions and Opportunity Costs}

On 7 September 1771 a convicted murderer called John Chapman was hanged at Chester. ${ }^{10} \mathrm{He}$ was executed in one of the main 'hanging-towns' in the North West of England. His execution rites soon proved to be controversial in the locality. Chapman resisted the hangman with considerable force. His body had therefore to be very roughly-handled to complete the death sentence. This potentially damaged the outward shell of his corpse before it was handed on to local surgeons. The controversial situation thus exposed common logistical problems that often damaged the criminal body badly before it reached its dissection destination. The courtroom facts were that Chapman was a sailor. He was convicted of homicide after a port brawl. Throughout the capital hearing he protested his innocence. It was rumoured that the trial evidence that convicted him was decidedly circumstantial. His fellow sailors thought him innocent and were angry at the death-sentence verdict. They consequently threatened to interfere with the Chester hangman. Chapman was equally indomitable. In prison he declared that he was determined to go on the offensive and resist execution. It was a priority therefore at the gallows for the legal officials to try to conclude matters speedily.

The standard execution procedure at Chester was that a clergyman was appointed to accompany the condemned to the hanging-tree. A spiritual counsellor was supposed to keep the convicted man or woman calm. They were also there to reassure the crowd that any repentance speech was genuine. The clergy had to attempt to bring about a final confession, being duty-bound to persuade the prisoner to atone murder to cleanse their soul. That confessional was written down and then printed as an intended moral lesson. Due legal process had to be seen to attend to the prisoner's spiritual needs and protect the well-being of provincial society. Chapman nevertheless refused to be consoled or counselled. On getting into the waggon with the appointed clergyman to travel to the gallows, 
the convicted man charged at his confessor's belly. The churchman was thrown violently out of the conveyance. The sheriff's officers seized the prisoner and 'tied him with ropes to the cart'. ${ }^{11}$ Still he struggled. On arrival at the hanging-tree he had to be strapped round the base of the gallows. Then the execution rope was prepared. The hangman 'had to try to lift him up to tie the rope about his neck'. Chapman reacted even more forcefully and lurching forward again 'got the hangman's thumb in his mouth, which he almost separated from the hand; he was at last tied up, but with great difficulty.' Ideally he should have been hanged for just over an hour. On this occasion he was cut down within a 'short time' to avoid a riot by the sailors and resentful crowd. It was a public order situation that could easily have got out of control. The executioner judged it necessary to react to the controversy by opting for a standard medico-legal concession. The condemned body on this occasion would be more badly damaged to finish the penal process without further delay at around the forty minute mark. Suffering was an objectionable but intrinsic part of the capital code. If the rope got tied in the wrong place or was not tight enough then the prisoner must suffer the painful penalty of being obdurate.

Generally medical men did not intervene to improve the condition of the body supplied to them because it was the business of the executioner to decide how and when to execute his duties. When therefore John Chapman was handed over to the surgeons his body had already been 'blemished' (by the initial tussle), 'bruised' (by the rope marks and manacles fastened very tightly in the cart), and 'battered' (having been strapped to the bottom of the gallows, gripped on the rope, and forcefully swung). He was despatched in haste, too hasty in fact; symbolic of the sorts of 'bad' bodies that surgeons often received which could vary a lot in terms of their physical condition even before post-mortem 'harm' commenced. Jon Lawrence indeed has indicated that anatomists were often not consulted about the ideal length or placement of the rope to ensure a quick death on the gallows. ${ }^{12}$ And this despite the fact that Simon Devereaux has found that English executioners generally lacked basic medical expertise compared to their European counterparts. ${ }^{13}$ To appreciate properly then the damage done to the criminal corpse and why at the hand-over this mattered medically-speaking to penal surgeons, it is necessary to briefly re-envisage the condemned dangling from the hanging-tree. The aim is to first build up a general historical picture of the sensorial elements before engaging with trial narratives that confirm the specific material circumstances in situ. 
Under the Murder Act, a common occurrence, hence, was that the hangman's rope generally marked the skin badly for surface anatomy. It was either tied behind the ear (a standard but inefficient technique as it often slipped) or to the front of the voice box (preventing the criminal from screaming out but usually prolonging death). Another medical shortcoming was that it was usual to measure the height, but not the weight of the body before execution in the eighteenth-century. This meant that strong necks which took a lot longer to break than the maximum period of one hour's hanging-time, troubled executioners especially those that remained unbroken even when cut down. ${ }^{14}$ A robust 'bull neck' allowed the vertebral and spinal arteries to function, maintaining continual bloodsupply to the brain. Even when the carotid artery in the neck did get cut off by the rope marks, the major systems did not drain of blood intandem. The force of gravity often enabled the rest of the body to draw what blood supply it could from the major organs and this was a powerful survival mechanism. Typically, the contemporary picture was that of a criminal starting to die by strangulation with their skin being stretched under their body weight and a dislocated but not broken neck. Most prisoners passed out from the excruciating pain, but they were still technically peri-mortem. ${ }^{15}$ If this lack of a neck break continued, and the rope was kept tightened, the cause of death was execrable. Blood stopped circulating in and out of the head. The heart meantime still tried to pump blood to the brain even though it could not go anywhere because the tautened rope restricted blood-flow to and from the head. There was equally too much blood inside the brain with nowhere to escape. An enormous buildup of head pressure occurred. Catheters in the brain became so pressurised they started to haemorrhage. The criminal brain in the process was turned to a bloody mush. ${ }^{16}$ The visible signs of this happening included eyes protruding like stalks, and the face turning from vivid purple to black: both were often reported in provincial newspapers. Then the criminal was in the most confusing medical state of all, 'the living dead' and few could legally determine whether this painful spectacle was torture or not. It was now that the executioner had the discretion to make concessions to appease the crowd.

The capital code decreed that the hangman did not have the option of using a sword or dagger to finish off the criminal. That penal authority had been revoked as uncivilised, by the early modern period. ${ }^{17}$ It was routine however to find other ways to speed things up. As a matter of course many hangmen elected to give the surgeon(s) on duty a rough-handled body. 
This had one advantage and one downside. If the execution method was rough-and-ready, the murderer would die when being mishandled. It thus averted the ethical issue of human vivisection. A 'bad body' could potentially limit how much original research and teaching the surgeon might want to do, but the criminal would in all likelihood become a corpse on the gallows. If, alternatively, a surgeon got a 'good' body that was less damaged by the execution, then he had gained a worthwhile research and teaching commodity. Yet, it might present him with an ethical predicament on arrival in the supply-chain. The tying of the hangman's knot was not therefore simply about an efficient execution. Its placement influenced the post-execution scenario too: a medical perspective often missing in crime studies of the period. In early modern England there was hence ongoing medico-legal debates about how, where, and for how long, to tie the hangman's rope on a criminal neck. Just how adept the medico-scientific thinking was on location was often disputed. Standards tended to differ in provincial and metropolitan settings. They were usually dictated by local and regional customs, as well as the executioner's preferred working practices. At Chester, the hangman always hoisted up the condemned prisoners facing each other because it was customary to accumulate criminals to stage double-hangings at each Assizes. ${ }^{18}$ The executioner used a black hood to cover each prisoner's face, with an underhand knot on the neck. This only worked smoothly from a medical standpoint if the condemned were co-operative and resigned to their legal fate. In cases where the convicted resisted execution to protest their innocence, like John Chapman, or had much stronger physical constitutions, medically-speaking methods of punishment ranged from the clumsy to inept. This contrasted with rituals in Leicester where the hangman worked faster than that his counterpart at Chester. Medically he prioritised getting the execution done to a precise medico-legal tempo. ${ }^{19} \mathrm{He}$ always started proceedings at the gallows as the city clock struck noon and then ended them when the hour chimed at one o'clock. The crowd therefore could countdown life ebbing away. The length of such hanging-times was nevertheless disputed, and again this mattered when it came to the timing of medical death and the general conditions under which surgeons first handled bodies.

Official eighteenth-century sources usually said that the standard execution time was 'up to an hour' but conflicting newspaper accounts often stressed that around 'twenty to forty minutes' tended to be the norm. ${ }^{20}$ At Tyburn for example in April 1733 four men were hanged for murder and their executions reported in the London Magazine. One of the 
felons, William Gordon, 'was said to have procured his Windpipe to be opened by a Skilful surgeon...'Tis imputed that though he was a heavy Man, he was observed to be alive after the rest were dead'. He was hanged for ' 3 Quarters of an Hour' but on being carried into a 'House on the Tyburn Road, he open'd his Mouth several times and groan'd'. In the opinion of the medical men present, most felons, even after being hanged for forty minutes, could fully recover ${ }^{21}$ At Bristol in September 1736 the Historical Chronicle reported a similar outcome. ${ }^{22}$ Joshua Harding and John Vernham were hanged together, cut down once they stopped jerking on the rope and displayed in two open coffins. Later they 'came back to life' in the house of the duty-surgeon. He bled them and had the foresight to declare to those assembled that they had a 50:50 chance of survivalHarding recovered but Vernham expired. After 1752, another contemporary commentator wrote of the execution rites of the Murder Act that: 'cases of semi-hanging are not a few, and, if those which are unknown, on account of the secret having been well kept, were made public, the list, I believe, would contain some score of names'. ${ }^{23}$ He claimed that 'tying or placing the rope in a particular way [generally to back or front of the neck instead of to the left-side of the windpipe] or by cutting it down sooner than usual, the hangman could render the subsequent revival of the condemned a comparatively easy matter'. In a medical sense then executions tainted by 'semi-hanging' and the 'half-hanged' betrayed the hangman's legal options to rough up the body, for reasons of corruption, to speed matters up, or to cover up basic medical ineptitude. The post-mortem sequel of events this created for the duty-surgeon mattered a lot less than the legal priority to carefully handle a public order situation that threatened social stability in a locality. The contemporary attitude was that the medical profession were lucky to get the criminal body even though it should have been guaranteed by the capital legislation. An odd medicolegal status quo therefore came about.

Once convicted in court the murderer no longer had any legal rights. Yet, the Murder Act had described the sorts of punishments that ought to happen next. This meant that in some controversial cases events at the execution could contravene the expectations of everyone. Gatrell has shown that there tended to be a spectrum of sentiments expressed on a hangingday. ${ }^{24}$ These ranged from the blood-thirsty in the case of a brutal murder, to considerable sympathy for the condemned if they seemed the innocentparty. Empathy was sometimes pronounced for harmless or gullible characters too. The sort of unlucky characters caught up in an unfortunate 
set of personal circumstances also won public sympathy. Any emotional outbursts during domestic violence that had escalated to culpable homicide resonated with the early modern Biblical belief: 'There, but for the Grace of God, go I'. ${ }^{25}$ Regardless, however, of the public mood in the execution crowd or the personal capacity of spectators to engage with an emotive storyline, there was a customary expectation that when the condemned was cut down they would at least 'look dead'. In general the attitude was that the person should still resemble the human being seen in the courtroom as they dangled from the hanging-tree and it was up to the hangman to be dignified and skilled about it. They could not therefore yet be less than human when taken by the surgeons. For the punitive steps to have moral authority and function as a capital deterrent, the executed body could be marked, mishandled, even broken, but not yet defaced or despoiled. The condition of the criminal corpse under these complex circumstances was hence subjected to the medical gaze of a lot of interested parties. They each claimed to wield official power or have moral agency over it: as Figure 3.1 illustrates (see, next page). This fluid contemporary context raises a fundamental historical question about whether it is possible to be more precise about the medico-legal damage being done to the peri-mortem body on what were three open-ended punishment pathways that happened concurrently and therefore are very difficult to disaggregate. They served the popular imagination, painful spectatorship, and criminal infamy (refer, discussion Chapter 1, page 11). At the handover one way to think again about these puzzling physical circumstances that involved medical steps to achieve legal ends, is to adopt Peter King's model of crime and justice for early modern England.

King envisages the English crime and justice system as a corridor of 'connected rooms' in the long eighteenth-century. ${ }^{26}$ Each 'room', he explains, contained decision-makers, motivated by a desire to realise their concepts of justice. King emphasises that each 'space' had a different 'shape' according to 'different legal constraints and customary expectations' behind a hallway of doors. There was a classic triangle of social relations present in each 'room' too. It was generally peopled by-the medical fraternityexecutive personnel that staffed the legal system-and the crowd-who all pulled and pushed for agency (refer, again, Figure 3.1). This judicial framework was overseen by state power, but it too functioned through its client representatives (medical and legal) and could not ignore the way that the criminal corpse was viewed culturally (by the crowd). Hence different social groups had different roles and their influence varied depending on 


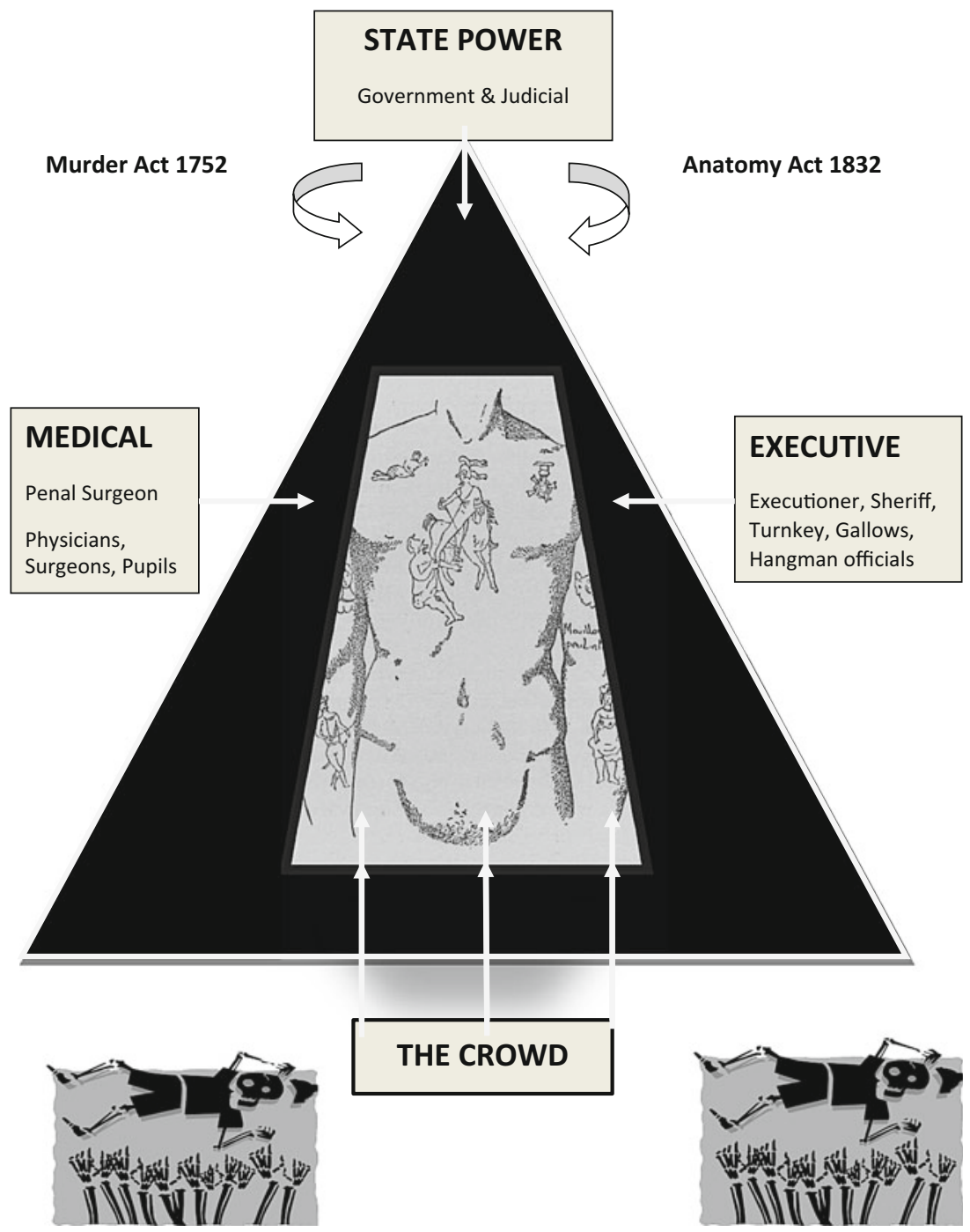

Figure 3.1 The medical gaze \& the embodied criminal corpse, 1752-1832. 
how far along the condemned body was in the punishment 'corridor'. By the time that the condemned had departed from the 'courtroom' space, it was moving into a medical territory in which a diverse audience was now assembled. The surgeons stood for 'science' on a path to full professional recognition but they had to work with the law-makers who had to make physical concessions to the crowd. The law and what could lawfully be done to the convicted murderer's body had therefore 'different meanings for different people' depending on the homicide case, logistical situation at the gallows, and the performance of post-mortem 'harm' the community expected to see.

Extending King's model, this book has found that it was also the case that whilst the various official and non-official actors came and went, congregated and dispersed at executions, by the time the condemned reached the criminal dissection 'room' everyone had come together again for the post-mortem encore. In a 'corridor' of 'rooms' inside the criminal justice process this was definitively the most crowded in the hallway of punishment options. And this is why to be 'thrust on up the corridor', as King puts it, ${ }^{27}$ mattered, not just in terms of completing a capital sentence, but what was about to be done by the exit also circumscribed how the entire punishment choreography was about to be viewed morally and physically. In which case, to anatomically check on medical death and its unstable condition, took on a symbolic importance, not just for medicine per se but eighteenth-century society as a whole. If then the medical gaze in Figure 3.1 was powerful, it was also continuously seeking to become power-laden. Surgeons thus relied on things going wrong at executions because these were opportunity costs that medicine needed to exploit to bolster its medico-legal prerogative. In terms hence of encountering the peri-mortem body in its proper historical context, it is necessary to rethink what the weather did to the condemned-how it metabolically shut-down - and the ways that chemical processes like peri-mortal digestion-all might spoil what was being handed over. The next few pages of discussion detail these essential physical circumstances before then proceeding to compare them to actual trial narratives.

It was not difficult to find things going wrong because executions often took place in places with logistical problems, as we saw in the last chapter. Winter cold sometimes caused extreme-hypothermic bodies, but summer executions presented equivalent difficulties too. The timing of the Assizes was in fact crucial. It coincided with the Quarter Sessions courts at the four religious festivals of Epiphany, Easter, Midsummer and 
Michaelmas. Mary Shelley thus wrote in Frankenstein, 'The season of the assizes approached' when setting out her famous storyline about resuscitation. ${ }^{28}$ Generally hangings staged after Easter were fore-shortened compared to winter executions, less than an hour; the recommended time span. This was because bodies rotted very quickly in the summer heat. So there were always local disputes about ideal rope lengths and optimum hanging-times. The official pressure tended to be more intense in summer to make a declaration of legal death to release the body before medical death. Samuel Hey of Leeds explains why this was so. ${ }^{29}$ Young Samuel when undertaking his medical training at Leeds Infirmary, where he did anatomy and dissection work, lamented to his brother the foul smell of decaying human flesh after execution during the Indian summer of September 1831. Samuel later elaborated in his private correspondence: 'I rather expect a post-mortem tomorrow, which I understand is the most horrible thing possible, on account of the intolerable stench' ${ }^{30}$ In a follow up letter he recounted: 'I had to trudge about a mile in the rain with William [his uncle] and Dr Hobson a physician in Leeds, about 9 o'clock at night and work at the chap for two hours, and then march home again carrying bits of him in my pocket, and a stinking case under my arm'. His clothes smelled of the stench of death and 'the worst part of the problem was that I pricked my fingers sewing him up but I sucked them as hard that it did me no harm'. He ended with: 'I certainly shall never wear the clothes I had on then, for no other purpose; no stink can compare to a body stink'. ${ }^{31}$

The Newgate Calendar likewise records how hard it was to execute in warmer weather. This outcome happened for instance at the doublehanging of William Proudlove and George Glover on 28 May 1809 at Chester. ${ }^{32}$ In the warm weather, the ordinary clerk related how the platform was dropped away 'but, alas, horrid to relate both ropes snapped a few inches from their necks, and the poor sufferers fell upon the terrace'. It was noteworthy that 'the miserable men appeared to feel little either in body or mind from the shock they had received'. In other words, they were 'in the name of Death'-their vital functions had started to shut down-but they were not in 'absolute Death'. The hanging time was too hurried, the substandard rope snapped, the murderers sweated too much, and so they revived 'and spoke of it as a disappointment' believing they were optimistically 'going instantly to heaven'. In this case, there was no mercy because they revived under the gallows and were therefore not technically legally dead. The executions were restaged the next day with much 
stronger ropes, a bigger drop and longer hanging time. The Historical Magazine similarly claimed in 1789 that at Exeter highwaymen were often suspended from a gallows and slipped the knot in summer weather when sweating with fear in the excessive heat. ${ }^{33}$ In the case of 'William Snow alias Skitch, for burglary, and James Wayborn, for highway robbery' both men 'fell to the ground' after the ropes started to burn under the heated friction and snapped. To the amusement of the crowd, Skitch cried out: 'Good people, do not be hurried: I am not hurried: I can await a little'. This time the executioner decided to 'lengthen the rope' and the men were hanged one at a time in front of a 'crowd of thousands'. Skitch was made to watch until Wayborn was cut down. The stronger rope was then placed on Skitch's neck and he remained on the gallows for several hours to make sure he was beyond resuscitation in the summer heat. The key point to appreciate in all these weather scenarios is that in homicide cases surgeons worked in grey medical territory. They had to somehow find ways to exploit the fact that criminal bodies would be damaged and mishandled as legal concessions were made in front of crowds when basic procedures became controversial or were sub-standard.

Envisaging then how the condemned body looked on arrival, began to visually decay, and started to smell badly, means historically rethinking a sensorial process and its biological events. Taking this practical approach involves revisiting the medical circumstances that have endured in death (rather than seeking in vain detailed medical accounts written by the crowd in an illiterate culture). For it is a material fact that the condemned in a history of the body has been a stable subject of biological continuity. Knowing how this works was an implied cornerstone of the Murder Act. That material recognition makes it feasible to retrieve what was an arresting experiential encounter that surgeons had to try to exploit. They were generally advantaged if it was a very gruesome execution with people being repelled to turn away earlier than expected. At the other extreme, an unspectacular, quick, send-off meant they could usually claim the body without being challenged. This sets in context why it was that nearly all contemporary newspaper accounts featured the condition of the hands and neck as notable indications of death by hanging. ${ }^{34}$ First-hand accounts provided a short commentary on the black bruising from the rope marks. The face was likewise commented on when contorted by blood rushing to the surface of the skin. The pallor, reporters recounted, generally looked clammy and then waxen-yellow once rigor mortis set in about four hours after the legs stopped jerking on the rope. Everyone, in all periods, looked like this at 
a hanging. It was a sensorial encounter that legitimised the actions of the surgeons at the hand-over and which historians can better appreciate.

The metabolic shut-down can be more accurately understood too. ${ }^{35}$ Medically-speaking chemical changes in the muscle had to have occurred after cellular respiration halted in the deep tissue of the condemned. Historically this has happened to every human being at about three to four hours after a fatal trauma. This timing explains when exactly the arms and limbs started to stiffen after being hanged on the gallows and at what point the surgeons hoped to exploit that physical situation. Hardening in limb-muscles would have been at their most rigid by twelve hours after metabolic death. Then twenty-four to thirty-six hours later the stiffness began to wear off, but slowly: it always depended on the ambient body temperature and this would have influenced the rate of tissue putrefaction. Early modern sources confirm that it was always much easier to handle a corpse immediately after an execution when the body was in a physical condition known as primary flaccidity. ${ }^{36}$ Since rigor mortis generally wears off around a deadline of twenty-four hours in everyone, this explains why many surgeons preferred to leave the body until the next day when the corpse could be easily handled. Sometimes they cut the tendons around the Achilles heel to stop the feet and legs stiffening, but in general there was a time lapse between being laid out for inspection to confirm medical death and being dissected to allow rigor mortis to wear off, as we saw in the case of Elizabeth Ross in Chapter 2. In winter, the surgeons worked more slowly on the body because rigor mortis in the cold took about six hours to take hold, rather than the standard three to four hours. In summer, the dissector knew that in the intense heat rigor mortis often happened much faster at around two hours. Whatever the seasonal time-span, the foul smell of decay was unavoidable. ${ }^{37}$ In terms then of the general condition of the executed, bodies hanged at the winter Assizes worked much better for surgeons everywhere.

There were physical aspects of the execution that hangmen and the executive personnel preferred to keep silent about, and which penal surgeons dealt with swiftly by shaving and washing the body on its arrival at a dissection venue (see also, Chapter 4). Again, these actions reveal opportunity costs to get the criminal body into a medical ambit more speedily to avoid public embarrassment and yet that logistical context has often been overlooked. Whereas for instance chemical changes and the problem of rigor mortis could be stage-managed, other body functions represented more of a taboo immoral issue. Legal officials refused to speak 
about how often the rope constricting the neck triggered an auto-erotic response in men during the summer heat when mishandling the corpse was a heightened problem. ${ }^{38}$ In summer flies and wasps buzzed around the expelling body fluids attracted by the sugary scent of sweat. Those nearest to the gallows got a strong whiff of urine ketones (smelling of cat pee) mixed with hydrogen sulphide (stinking faeces stools) because many criminals literally wet or defecated at the fatal time; others smelt of alkaline bases of chlorine (ejaculated semen) too, aroused by the imagined terror. Grabbing hold of a male body in these slippery conditions and manipulating the sexual organs before public display at a dissection venue was a test of a surgeon's dexterity. They could generally work behind the scenes assisted by the executioner because handling such tasks was considered distasteful in front of a crowd containing boisterous men and receptive females said to be impressionable. When women were hanged the physical purging was vivid red too, since an unpleasant side-effect was that females tended to menstruate spontaneously. The pull of gravity on the lining of the womb generally caused a prolapse of the sexual organs as the torso stretched downwards. ${ }^{39}$ Barber surgeons trained in naval and military warfare were familiar with the scents of blood products, but the fishy odour of menstrual evacuation mixed with bacteria in the vagina when exposed to fresh air was still a disquieting side of their penal work. A cultural of denial also surrounded the side-effects of the basic functioning of the involuntary hyper-arousal mechanism (mentioned earlier and discussed in Chapter 2). Essentially the sympathetic nervous system activated the adrenal medulla in the brain to secrete catecholamine's norepinephrine and epinephrine. ${ }^{40}$ These have four unavoidable outcomes relevant to an executioner's handling/mishandling of the condemned as they expired: blood flow increases, blood pressure rises, blood-clotting speeds up, and muscle tension stiffens to provide the body with extra speed and strength. Three of these together better oxygenate the blood, and provide a very powerful survival mechanism when in a traumatic situation. Yet, few historical accounts trace such a commonplace biological chain-reaction and its chemical impact on the criminal body. Common medical symptoms beyond historical dispute have thus tended to be overlooked or misconstrued. Surgeons that sensibly elected to clean or manipulate the sexual organs and trim off all the body hair at the hand-over took necessary sanitary precautions. Yet, the processes of preparation for dissection also covered up the unsavoury side of execution that they were exploiting to bolster their medical prerogative too. 
Digestion adds another dimension to biochemical death by execution and it likewise could be exploited by the surgical community. It was a biological fact that 'different parts of the body decayed at different rates' to complicate criminal dissections. ${ }^{41}$ The bacteria in the gut did not die when the criminal was hanged. In all human beings microbes keep on functioning in everyone after death (regardless of how the person expires). They feed off the last meal and are then expelled as noxious gas post-mortem. The smell lingered for those working in close proximity to an execution because gaseous exchange goes on occurring for up to six hours until involuntary digestion ceases. If someone was young-and most of those executed for capital offences were males aged between 20 and $40^{42}$-then their body tended to be healthier. This meant that their flesh decayed more slowly than the corpse of a diseased person that was older. ${ }^{43}$ In the past, if the body was placed under a flowing water tap-common in the basement of some provincial dissection rooms - then again this could slow down decay. ${ }^{44}$ In general, a criminal body 'decomposes in air twice as quickly as in water and eight times as rapidly as in earth'. ${ }^{45}$ An unpleasant aspect of this digestive shut-down was that when gases accumulated in the lower abdomen a side-effect was that the lungs were forced upwards in the chest cavity. Decomposing blood had to escape from the mouth and nostrils. Once this happened it was easier for the surgeon to be in a position to claim the body. It 'looked dead', still resembled a human being, but was self-evidently moving into a new punishment phase in which they could claim more expertise than the hangman. A related physical characteristic of this bloody purge was eerie. It adds to our historical appreciation of why there was often a subdued mood amongst the crowd commented on in contemporary newspapers. Once rigor mortis happened in the dying body the wind pipe in the neck area stiffened. The corpse was now filled with gas that needed to escape but not all of it could leave the anus, and since escaping blood blocked the nose and nostrils, some air had to be expelled by passing over the windpipe. It could be heard as moans, groans, squeaks and rasps by those witnessing the death. This biological soundscape might sometimes have been lost in a noisy crowd at the execution, but once the legs stopped jerking another feature of the punishment ritual seems to have been to listen out for the death-rattle.

In terms then of the body's basic condition when a medical official wanted to take over legal responsibility, to the touch it would have been grey, flaccid, often waxen, and the skin was bruised a lot, fragile, paperlike, especially around the iron-manacles or rope-marks. Hand and toe 
nails looked longer because the skin retracts when circulation slows with the last shallow breathes; likewise the hair seems lengthier. The jaw dropped in criminals with teeth in a poor condition. This was not unusual in the eighteenth-century when decayed gums receded a lot; some also sold their teeth to dentists to pay for a good send-off. ${ }^{46}$ Altogether it was commonplace to see mouths sunk into faces. It would have been an arresting sensorial experience to look at such criminals, either close-hand, or when trying to handle them. Criminal histories do highlight that there were 'degrees of death' and 'numerous ways to die at the execution site' in the eighteenth-century, but few examine the longevity of their sensorial or medical dimensions in-depth. ${ }^{47}$ As one English commentator wrote: 'Tis well known there are some kinds of Death more sharp and terrifying than others ${ }^{48}$ This reflected how for those crowding round the corpse there were 'two kinds of dead: one in Nature, the other in Culture' as it lay on the ground. ${ }^{49}$ It meant that in terms of bodies leaving the execution scene for punishment accompanied by large crowds 'the corpse and the person [were] not irrevocably sundered'. ${ }^{50}$

Although therefore Georgians lived with the foul smells of humanity in their over-crowded neighbourhoods lacking basic sanitation, it was more desirable for surgeons to pay the price of obtaining bodies by letting them take over. Yet, this very important medical context seldom features in standard cultural or criminal histories with the exception of Gatrell's admirable work. Essentially, as Esther Cohen remarks: 'The ritual was worthless unless people knew and understood its symbolism': to be given access to a body cut down for a criminal dissection close-hand was all about the immediacy of its material reality and its unsavoury nature became the business of the surgeon. ${ }^{51}$ Resented many may have been pre-execution, but increasingly not post-execution, when the condemned was in a 'bloody mess'. Making the punishment 'alive' or 'fresh' in people's minds was about slippages - shedding, smelling, swelling, and shrinking. A representative selection of trial narratives brings these ubiquitous sensorial experiences into view and sets the opportunity costs they implied for provincial surgeons in their historical context. Two high-profile trials highlight medical narratives that were well-publicised in the retelling, revealing how medico-legal officials worked under challenging conditions, in Sections 2 and 3. Later in Section 4 will see that much of the headline detail was also duplicated in the East Midlands. In this way, the substance of the detailed trials in Sussex and Surrey outlined next, also relates to a spectrum of bodies handled by surgeons elsewhere under the Murder Act in provincial English life. 


\section{Bull-Necked Bad Bodies: Medical Narratives on Trial in SusseX}

In August 1831 a shocking murder was to make national headlines. The brutal killing and the gruesome disposal of the human remains of Celia Holloway raised distressing questions. The homicide was a textbook copycat killing. It mirrored how retribution by penal surgeons was done to the criminal corpse in death. Newspaper reporters investigated what motivated John William Holloway to murder his wife Celia. They wanted to know where he learned to duplicate anatomy and dissection techniques. John confessed to local magistrates in Brighton that he tried to strangle Celia with a cord, then hanged her with a rope, quickly cut down the corpse, and afterwards dissected and dismembered his estranged wife. Celia was pregnant with John's child (even though they had been residing apart before the fatal day). He was currently living in Brighton with his accomplice and mistress. Celia lived nearby but John had deserted her. He was determined to kill his liability. In three remarkably detailed confessions Holloway described how he adopted standard execution methods to his deadly-design:

I then tied the cord as tight as I was able and then dragged her into the cupboard, and hung her up to some nails that were placed there before. As I dragged her into the cupboard, I felt the poor dear infant struggle in its mother's womb, surprisingly strong indeed. Oh what a shocking sight! I shall never forget it. I did not remove the cord from Celia's neck, but took an over-handed knot, and I made the ends fast to the nails, so that she was hanging by the neck. I proposed then cutting her up; but Ann Kennett [his lover] told me to wait until the blood was settled. ${ }^{52}$

In Horsham jail John Holloway elaborated to his confessor what it looked and felt like to kill his former wife, an act of pre-meditated murder:

When I called Ann Kennett [accomplice] from the cupboard, I believe that poor Celia was able to see the person whom I called, although her eyes were nearly turned into her head; yet, when Ann Kennett appeared, her wild appearance increased; the cold sweat in big drops on her pale cheeks; and almost as soon as Ann Kennett took hold of the cord [to pull it one last time], poor Celia dropped. Her wild appearance seemed to terrify Ann Kennett, as well as myself; for Kennett said to me, 'Oh how wild she looks'. I made no answer that I can remember. At the time that I committed the horrid deed, I am not able to describe my feelings; but I think you will understand me when I say that I had none. ${ }^{53}$ 
John admitted that he resented his wife for compelling him to marry when he was ' 18 or 19 years old...she was with child by him after their intimacy, and almost seven years ago the poor law overseers compelled him to marry her. They lived for some time pretty comfortable, and might have continued to do so, but for the ill usage of her relatives'. ${ }^{54}$ He claimed that he was always being criticised and then was shunned by his in-laws for his lack of financial acumen. Eventually John ran off to sea, before returning to co-habit with his lover Ann Kennett (sometimes called Kinnard). The Preston parish overseers, near Brighton, his former wife's relatives, and others in the Sussex neighbourhood, meanwhile continued to induce him to pay Celia a weekly maintenance allowance. His fury, he claimed, turned to paranoia that they all wanted to 'destroy his peace of mind'. Young love had evidently turned to hate. John thus planned to briefly co-habit with Celia once more to regain her trust (this accounted for her pregnant condition at the time of the murder) before luring her 'to a private place and assassinate her'. Having 'cut the body up', he confessed to putting the parts 'in a trunk, dug a hole and buried them' in a local park. In point of fact a local constable rediscovered the dismembered head and limbs in a privy. Meanwhile John's lover was arrested too for being an accessory to murder. ${ }^{55}$ The sensational elements of the case gave rise to a lot of speculation as to why John was so impressionable. He had not just observed, but admitted adapting methods of execution and dissection he had seen to suit his deadly purpose. Evidently the capital punishment process of the Murder Act was well-known and had enticed someone susceptible to commit a violent crime: the opposite effect intended in the legislation.

The unwitting testimony contained in Holloway's confessions is instructive. It reflects more broadly how the body's fate on the gallows and its post-mortem punishment entered popular culture. John confessed that by 1831 it was generally known that it took an 'over-hand' knot to secure a body on the end of a cord or rope because a lot of executions had been bungled before the crowd. He tells us that he attempted to strangle his wife but found it very hard to kill her quickly by the 'ordinary method of strangulation'. This is why he decided to tighten the cord, elevate the body under a strong knot (he used a trefoil the second time), and got an accomplice to help him tighten the noose: techniques adapted by executioners on the gallows. He knew there had to be a 'drop' from which the corpse was suspended but he could only create a 'short-drop' when there clearly needed to be a 'long-drop' to hasten death. John related his impulse to cut up the body to get rid of the physical evidence but his accomplice 
understood that the body works with gravity and drains of blood from the head to the toes when dying-Anne 'told me to wait until the blood was settled'. As we have seen in Chapter 2, new scientific ideas were in circulation that challenged the out-dated idea that cardio-respiratory failure was medical death. That explanation was old-fashioned because of anatomical research on the brain's ability to survive head trauma (refer, also Chapter 6). By 1831 it was known that the brain drained of blood in death, and not until then would the person truly expire. Indeed in jail Holloway confessed that Celia hanging on the end of the tightened cord was sensible of her murderers despite the excruciating pain. Holloway noted her physical reactions - a 'cold sweat', 'big tears', 'pale cheeks', 'eyes nearly turned into her head', and a 'wild appearance'. Being hanged by the neck looked physically like this for everyone and because it was well-known this part of his evidence was not contested in court.

Under cross-examination John Holloway conceded that once he started to dissect the limbs the fresh 'blood went everywhere'. ${ }^{56}$ The prisoner remarked that the practicalities of dismembering a corpse were far more gruesome than he had anticipated. In his arrogance, he revealed that he knew the basics of how to do anatomy (cutting open the body and looking) but not dissection (dismembering it into body parts). He soon discovered the latter's dreadful side. It is worth keeping in mind that dissectors had no latex gloves, suction tube, or electric light to work under in the long eighteenth-century. Fresh blood could spurt all over the candle-lit dissection table, especially if the anatomist was inexperienced and cut the stomach or intestines containing the prisoner's last meal. If they did, the smell of food-decay could knock them out. This is one reason why the condemned was usually just fed bread and water at their last meal: again, a seemingly trivial but important physical part of the execution ritual often overlooked in criminal history. Naturally contemporary courtrooms were in the thrall of such gruesome confessions. Newspapers in Holloway's case made a number of medical observations relevant to the discussion in this chapter. All noted that the death penalty had a dehumanising side. Even experienced hangmen in high-profile cases preferred to have surgical assistance. Not all necks broke on the rope, and a prisoner's willpower could defy the procedures of capital death. Medically-speaking surgeons took advantage of this situation. Yet, the crowd increasingly had an accumulated knowledge about why it was desirable that they did so. The unsavoury aspects of cutting up a warm body, revealed by Holloway in court, confirmed that it was best to let a surgeon handle those that 'looked dead' in reaching post-mortem 'harm'. 
The authorities in Brighton were so appalled by the brutality of Celia Holloway's murder that they sent for an expert executioner from London. In court John Holloway stated that it was his intention to make a dramatic entrance at the gallows by dressing in a black-cloak. The trial judge dismissed such theatrics as self-serving. According to local newspaper reports, the prisoner's bravado held up until he faced the actual gallows. A local account described his countenance as 'grief-worn, pale and cadaverous' with a 'restless oscillation in his eye' ${ }^{57}$ The dramatic adjectives and building of theatrical tension did of course serve to increase newspaper sales. Nonetheless, it was common to witness a prisoner with agitated eyes and a pale face, usually caused by stress. Insomnia was also a physical factor since few slept well before the fatal day. In John's case, the hangman 'tied his arms and hands' and it was reported that for the first time the prisoner 'exhibited signs of fear, trembled excessively, and expressed in a low tone of voice a hope that he would not suffer excessively'. Local records stated that the rope was placed around Holloway's neck and was 'at least three feet in length'. The hangman now stood in front of the chest of the condemned whose 'heartbeat was racing'. In all executions, the autonomic nervous system in every human being was reflexive like this.

The court records confirm that the executioner of John Holloway was highly skilled. Newspapers likewise stressed that 'a medical gentleman was present' to monitor death. Procedures were meticulously managed for publicity reasons. Given the notoriety of the prisoner, full justice had to be seen to be done, and efficiently. We thus learn from local accounts that Holloway's 'chest heaved' as he grasped for breath; 'his clasped hands quivered, and dropped'; there was a 'convulsive movement of his lips'. It was then reported that:

After the body had hung about a quarter of an hour, a man ascended the scaffold with the executioner, and seating himself on its edge, took off his hat. The hangman then loosened Holloway's hands, the palms of which he rubbed on the forehead of the countryman under the absurd notion that the death sweat would remove the excrescence [monstrosity]. The executioner (the Newgate hangman) was to be paid half a crown for this disgusting spectacle. The under-sheriff, however, very properly gave him to understand, that he would not suffer a repetition of such proceedings until after the body was cut down. ${ }^{58}$

The account described how a local parson was permitted to also climb on top of the scaffold and give the last rites after fifteen minutes as a 
precaution because local opinion held that medically-speaking death was indeterminate. It was popularly held by evangelicals in Sussex that the soul darkened by sin needed to have spiritual help to disconnect from the bad body. Equally there were those present who believed in a version of the superstition of the 'dead hand': in this case wiping the forehead of the 'countryman' with the prisoner's sweaty palm was said to release the spectre of monstrosity to the judgement of God. The local newspaper reporter took a more Enlightenment attitude. He questioned 'the fitness or unfitness' that 'such public religious harangues at the moment when a fellow creature hangs suspended from the gallows'. He also noted that a fifteen minute duration was too short to declare medical death and that as a further precaution the executioner checked again after 'one hour, the 'usual time', when the hangman 'ascended the platform, and untying, not cutting, as was formerly the custom, the halter, the body fell into the arms of the turnkey, who stood beneath'. The reason for carefully undoing the knot was even after sixty minutes a faint pulse was sometimes felt. Holloway could revive by the very act of releasing the rope and this made him dangerous. The corpse was thus removed into a room nearest the scaffold, where the hangman took the rope from the neck, which on the knot to the left side was deeply cut by the ligature. He then stripped off his clothes, his prerequisites, and the body lay naked on the floor. On examination by the surgeon, the neck 'proved not to be broken, from the extreme strength of the muscles, the deceased being what is termed bull-necked'. ${ }^{59}$

John Holloway's condemned body in capital death was not yet a corpse more than an hour after being hanged. It had been inscribed by the symbolic processes of social and legal death, and the metabolic procedures of medical death were underway but not yet finished. These required a number of interventions even before a dissection venue was decided. The body was stripped of its clothing to start to erode the prisoner's identity. The naked corpse was laid on the bare ground to demarcate it as 'the other' in society and, yet, it had a medical potency. The court record confirms that a young man from Lewes who assisted the under-sheriff was given the hangman's rope to sell to 'for a gratuity'. This folk-belief reflected local customs about the potency of the gallows-rope as a quack cure or cabinetcuriosity in Northern Europe. The body now had to be made safe by the surgeon. This was after all someone considered to be dangerous. There was an unbroken neck and it was essential to cut the carotid artery. It was therefore not a coincidence that John's body was left on the ground after 
execution. Raising the head slightly to cut a body lying in a prone position (face-up in this case) was the best way to do a mercy-killing in the neck area to speed up the dying process: a new medical perspective of criminal justice. Severing the carotid artery had the added advantage of keeping the torso blood-free because body fluids drained behind the head before rigor mortis set in. These basic procedures were ethically questionable and an opportunity cost for the surgeon, as well as seemingly merited in a murder case that had inspired a public outcry. One local newspaper reporter who followed the case throughout thus described the work of the appointed surgeon on duty as: "like a tempest in the natural world, which although it might inflict a partial evil, is in the end productive of the general good' ${ }^{60}$ In its scientific performance, medico-legal procedures going wrong in this case are instructive about the shifting historical standards of crime, justice, and punishment rites in provincial England under the Murder Act.

John Holloway's corpse was brought into the dissection room of the Brighton voluntary hospital. It was said in local newspapers that it would be 'publicly displayed the following day'. Later reports stated that it was a 'spectacle...to which hundreds resorted'. Afterwards it was dissected 'to its extremities'. In practical terms this meant that the surgeons on duty did three key things. First, they double-checked for life-signs. The body was then secondly washed down with camphor to try to kill the rotten smell. Thirdly, it was shaven all over to prepare it for dissection. This third procedure marked the condemned as the ultimate outcast. The razor cut the final connection they had in mainstream eighteenth-century society because having hair all over when alive had real significance. Most people were hirsute at the time. Beards were bushy, bodily hair was seldom shaved; pubic, back, leg, and under-arm hair grew prolifically and was very fashionable. Thus for instance when John Hogdkinson from Hereford visited London in 1794 he wrote in his diary about how surprised he was to see the close-shaven Turkish Ambassador and his retinue: 'They had no beards' he exclaimed, 'except what grew on their upper lips!' ${ }^{61}$ His surprise reflects the fact that most Englishmen were long-haired. Both men and women's hair was at least collar-length at a time when tall powdered-wigs were in vogue. It was rare in Georgian society for any person to be depicted without hair unless they had taken the King's shilling to join the army or navy. Shaving the criminal corpse bald thus publicised a dangerous social pariah.

This common observation was a central feature of perhaps one the most famous murder cases in criminal studies, namely that of William Corder executed for the infamous Red Barn Murder at Bury St. Edmunds 
in $1827 . .^{62}$ Once shaven local newspaper reporters claimed that a lot of young women came several times to see his coarse head laid out in the dissection room (refer, Chapter 6). Primeval notions of survival of the fittest evidently existed before Darwin labelled them. The human psychology of coarse appearances may have held some sort of basic physical attraction between early modern men and women. As Albert Mannes' recent work explains in past societies 'men with shaved heads were rated as more dominant than similar men with full heads of hair... men whose hair was ... removed were perceived as more dominant, taller, and stronger than their authentic selves'. ${ }^{63}$ It is an intriguing possibility that stripping John Holloway's corpse, shaving his head, and washing him for post-mortem punishment, might have enhanced his powerful attraction for those that crowded round. Holloway was not simply an exhibition of terrible retribution; he could be an exciting primitive encounter too. Taken together, sources depicting John Holloway's case set in context why there was a dangerous frisson in the air on arrival at the dissection venue. His body debauched by immorality, strangely shaven, exuded a masculinity that had a bad criminal stench. ${ }^{64}$ It was this context too that arrested crowds of people in Surrey at two notorious executions when the medical condition of the condemned bodies became the focus of popular attention in our second detailed trial narrative of the early nineteenth-century.

\section{Proverbial Bad Men with Bad Bodies: Medical Narratives on Trial in Surrey}

In the early morning of 10 November 1817 two bodies were found dead in a town-house in Godalming, Surrey. ${ }^{65}$ William Parsons, a local surgeon, examined the corpses. He informed the local coroner that he found two murder victims: 'He saw Elizabeth Wilson on the floor, with her throat cut and other marks of violence on her head. She was cold and stiff. The wounds appeared to have been afflicted a considerable time, and the wounds were flaccid and cold. ${ }^{66}$ Upstairs Mr Chennel, the propertyowner, was dead in bed:

reclining on his right side, with his throat cut and his skull fractured [He] thought life was suspended by the blows of the hammer, and his throat afterwards cut, and the reason this was the course of the proceeding was, that there was not such a flow of blood as there would have appeared if the throat had been cut first, while the pulsations of the heart were still active ${ }^{67}$ 
Extensive enquiries were instigated door-to-door to establish the estimated time of death. Sometime between 9 and $10 \mathrm{pm}$ there was a short killing-spree. The coroner concluded that there was probably more than one perpetrator. He informed the Inquest jury that the murderers were either arrogant, over-confident, or had little remorse, because they left behind a blood-stained carving knife and large hammer. The forensic evidence indicated that the two homicides were pre-meditated, carefully orchestrated, and this enabled the killers to make a silent getaway.

In the coroner's court witnesses testified that John Chennel junior was in debt. He had recently separated from his wife and was desperate for ready cash to entice a new lover. His father refused to fund his son's dissolute ways. On the fatal night John robbed him. Elizabeth Wilson, the family housekeeper, tried to prevent John stealing two pounds from his father's coat-pockets. He thus murdered her downstairs. Upstairs meanwhile an unscrupulous man-servant called John Chalcraft killed John Chennel senior. The Inquest jury were told by a dozen witnesses that Chalcraft 'was an infamous character, and ought not to be believed unless confirmed by other testimony'. ${ }^{68}$ Parricide and the murder of a master by his servant were perfidious charges. To secure a conviction there needed to be meticulous evidence-gathering. It would take nearly nine months to bring the case to trial. In due course, on 14 August 1818 at the Summer Assizes in Guildford John Chennel and John Chalcraft were found guilty of the Godalming murders. ${ }^{69}$ The judge used his sentencing powers to decree that the penal punishment must be a very public affair. The Godalming murder story is then in many respects an historical prism that illuminates the ongoing medical position of surgeons in the legal processes of punishment for homicide under the Murder Act by the early nineteenth-century.

On 15 August 1818 a large crowd congregated in the centre of Godalming to witness the execution of Chennel and Chalcraft. ${ }^{70}$ An editorial in the local press reported that the number of people was immense and lined the road as far as the eye could see...In the narrower places they were pressed together so closely as to be endangered by the horses and raised clouds of dust that literally enveloped them'. Most were dressed as 'farm servants' for the reporter noted that he had never witnessed 'so many smock-frocks and straw-hats' assembled in 'mournful procession'. The Under-Sheriff for the county of Surrey ordered a gallows to be constructed on Harvest Saturday near the murder spot. After execution the bodies were to be returned to the fatal premises where the original homicides were committed to undergo a 
symbolic dissection. This public recourse to physical retribution was not in fact unusual but the local record of what happened next was more detailed. The trial accounts state that the 'bodies were cut down and given to the two surgeons of Godalming, Mr Parsons and Mr Hayes'. August, as we have already seen, was the worst month of the year to obtain an executed body because putrefaction happened much faster than in winter or spring. After twenty-four hours the human material had started to smell badly. Another practical problem was that in summer the bodies could only be left on the gallows for the minimum-time. By convention the court record usually said that each hanging took an hour. But these official records were sometimes written before the day of execution so that official accounts of how the prisoner repented and confessed their sins could be distributed to the crowd to increase the moral value of the execution spectacle. Local newspaper reports tended to be more historically accurate about actual hanging times, even if the general tone was sensational to sell copies. The key point to appreciate is that Surrey journalists did report much shorter hanging times of around forty minutes depending on the season. Hanging from the rope like this was practicable but medically suspect. Hence the Godalming records state that 'the two prisoners were brought out, with irons on their feet, hands pinioned, and the rope with which they were to be hung round their waists'. The executioner carried a 'drawn sword' but he only used this to keep public order. He did not deploy his weapon of office to stab the heart or behead the corpse on the gallows, like in Tudor times. Making sure the criminal 'looked dead' was a short-run performance of rough retributive justice. Everyone was in a hurry to get the hangingstage done at the height of August's harvest heatwave.

Surrey court records confirm that the bodies of John Chennel and John Chalcraft were 'cut down... received into the waggon' which doubled up as 'the elevated stage for execution' ${ }^{71}$ Provincial newspapers claimed that contemporaries held that there might still be a sign of life after hanging on the rope for a 'shorter timespan in summer'. This is confirmed by the 'curious way' that the crowd now acted in Godalming. The bodies were 'conveyed in slow and awful silence' accompanied by those present walking alongside the wagon in procession. They listened and watched over the bodies for any visible life-signs. The mood was not just poignant, it also reflected medical practicalities. The crowd proceeded with precaution. The surgeons were not given any special access to the bodies at the gallows. Their opportunity cost to obtain a medical prerogative therefore came later in the punishment choreography than those cases discussed 
earlier in this chapter. Local opinion nevertheless held that some 'murderers had a stronger life-force' such was their determination to evade natural justice. There was hence a 'solemn, slow, and symbolic procession' that did not sensationalise the spectacle of the corpse now that they were 'in the name of Death'. The crowd instead stood watchful at the threshold of life and death. The surgeons now took centre-stage as they dealt with the medical condition of the peri-mortem bodies.

Mr Parsons and Mr Haynes were waiting on the criminal corpses: strictly speaking they were both body and corpse, as they were in a condition of medical 'limbo'. In the kitchen of the Chennel townhouse the post-mortem 'harm' got underway. The court record and local newspapers reported that Mr Parsons 'performed the first office' and this was an anatomical check of the sort seen in the last chapter. ${ }^{72}$ He took a lancet and opened the torso from the navel to the neck, in turn, laid out on two kitchen tables horizontally. As the court record states, 'the bodies in this state were left to the gaze of thousands, who throughout the day eagerly rushed to see them'. The reason that they did so was because the anatomical cuts exposed the major organs, including the heart. If there was any sign of life, then the surgeon's first duty was to use the lancet to commit a merciful act. In other words, the 'first office' (to use the exact contemporary phrase) made the surgeon's lancet the executioner's medical accomplice. Only then, would he proceed to the 'the second office' of post-mortem punishment by dissection. Local newspapers in Godalming described the latter as 'awful... they may be imagined but not described'. ${ }^{73}$ It was understandable why contemporaries would take this editorial line. Post-mortem punishment was supposed to be a deterrent. If the opening of the corpse was restricted by custom to the public view of an anatomical exposure to check on medical death, then dissection had the potential to instil more fear. From the surgeon's viewpoint these local sensibilities also gave them the opportunity cost they had been waiting on. It was now feasible to arrange that as there was not enough physical space for the execution crowd to be part of the dissection in the kitchen, they should exit before the extremities were cut from the torso. In Chennel and Chalcraft's case, and numerous accounts elsewhere that we will encounter later in this book, very few tried to stay behind. The condition of the corpse that ordinary people wanted to crowd around was generally one with recognisable human features. It was a complete body in the sense that the limbs were not yet severed and the head was not decapitated. In terms of Northern European sensibilities surrounding body-integrity in death, at criminal dissections the essential wholeness of condemned bodies had enduring 
appeal (a theme elaborated in Chapter 6). Meantime, many murderers in 'jail' were said to be in 'limbo'-an eighteenth-century term for sinful souls that had crossed a threshold of immorality requiring the redemption of capital death. ${ }^{74}$ Typically, these sorts of condemned bodies were handled by the Nottingham Assizes and they highlight the common logistical problems of provincial surgeons in many locations outside of London.

\section{Criminal Bodies in Limbo: An East Midlands Medical Perspective}

Samuel Haywood was a very experienced executioner from Appelby Magna who carried out forty-four executions in the East Midlands, covering Leicestershire, Derbyshire and Nottinghamshire during his tenure from 1820 to $1847 .{ }^{75} \mathrm{He}$ was also hired by Gloucester, Lancaster, Liverpool and Warwick Assizes in recognition of his proficient skills. Newspapers followed his adeptness with alacrity. Reporters highlighted the logistical difficulties he overcame that confounded others. A detailed record of his final execution at Derby in April 1847 reveals for instance how in the case of a condemned murderer named John Platts his light-weight body caused a lot of logistical medical problems. Haywood had to place extra irons tied on the feet of Platts because the condemned was just 'four foot eleven inches tall', 'stocky', and 'trembling'. ${ }^{76}$ It was no easy matter to ensure that he died on the gallows. Such a small man took a lot longer to die in a fraught state because the force of gravity did not work so well. Local reporters stressed that 'even with the extra irons secured to his feet, his neck did not break'. His hands and feet 'were seen to rapidly jerk to and fro as far as his irons would allow, and then slowly as if a tipped bottle was emptying, all motion ceased'. He did not try to run away since this was impossible but fear (the classic 'fright' response) was seen as a factor in his painful execution. Hence, Platts was hanged for 'over an hour', cut down, and checked anatomically by Haywood and a surgeon. They did so very carefully and the crowd did not disperse but were described as 'very orderly', 'quiet', and 'subdued' by newspaper reporters at the scene. Pathos was a powerful experiential part of the medical rituals. It also gave surgeons the medical prerogative to get more hands-on when things became emotive as death's dominion was contested. Even a skilled hangman relied on a medical official to make sure that the condemned was lifeless. John Platts' physical short-comings were an opportunity cost not to be missed or indeed mistimed. 
The position at Nottingham, where research material is rich in detail, was that surgeons needed the body to establish their professional status as soon as it was timely to do so in the execution process. They were always confronted with one logistical problem. A dutiful executioner might rough-handle the condemned for a lengthier time period. This placed the duration and extent of post-mortem 'harm' at risk. Strategically therefore for the penal surgeon the ideal situation was to be in a medico-legal position to exploit the condemned peri-mortem. The criminal 'looked dead' in a near-death situation, but was not strictly-speaking in chemical putrefaction (in death, cell membranes become permeable and break-down releasing cytoplasm; this chemical medium contains bacterial enzymes that cause putrefactive changes in the deceased). In the East Midlands, and elsewhere, most penal surgeons got involved as close to the hanging-tree as they dared. This backdrop, emphasises why anatomization developed into a distinctive stage in the punishment choreography. In the last chapter we saw that it became a standard checking-mechanism for life-signs on arrival at a dissection venue. It was also a clever penal device to let the surgeon deal with robust bodies. Many near-death situations might otherwise have been delayed coming to them. There was no need to inflict more damage on the hanging-tree if medical expertise was prepared to finish the task. That tactic agreement meant that surgeons learned to exploit whatever concessions executioners were prepared to make to them. Extensive damage to the body to complete the death sentence of a dangerous murderer was never outlawed (quite the reverse). It was different timings and understandings of discretionary justice that shaped the actual moral standing and practical working relationships of medico-legal officials across the East Midlands. In the end, the penal surgeon's medical prerogative was decided by body types and the timing of capital death on the Nottingham gallows: the medical logistics are therefore illuminating in the archives.

The Stranger's Guide to Nottingham (1827) described how local executions had traditionally taken place at Gallows Hill on the outskirts of the town. The hanging-tree was then moved to the front of the Shire Hall, which was rebuilt around the time of the Murder Act. It was: 'A good brick building, faced with stucco. In the front is a clock, which strikes the hour upon a bell on the roof of the building'. Its purpose was to count down each execution, for, as one contemporary wrote, the clock-bell has 'a very fine mellifluous sound and was heard at a considerable distance. ${ }^{77}$ To control the large crowds, 'The west front is guarded by iron palisades, through which we pass by a flight of stone steps into the hall, where the 
assizes and sessions are held, and also the Mayor and Sheriffs' court once a fortnight, and the Sheriffs' county court once a month.' The gaol was conveniently located here too and a door in the high-pavement opened to take prisoners down into cells cut out of caves, a natural occurrence, in the subterranean underworld of the town-centre. Situated opposite was St. Mary's Church with a convenient graveyard in which to bury the condemned, but not before local surgeons had an opportunity to punish the corpse post-mortem. From the 1760s they received all sorts of bodies in a variety of physical conditions and medical circumstances. This reflected how Nottingham developed a number of execution traditions that were influential across the Midlands. ${ }^{78}$ It had for instance been accepted practice to compel the condemned to attend a final sermon at St. Mary's Church on the day after sentencing but before their send-off. The Biblical theme of the 'wages of sin are death' was preached from the pulpit by a clergyman exhorting repentance. If prisoners were not penitent then a second tradition was to take the condemned out into the churchyard and get them to lie down in their newly dug grave to make sure it fitted their body size: a misleading public relations exercise since after dissection there would not be much left to inter. A third way to prepare the prisoner for atonement was to dress them in a shroud and lead them through the town-centre in a public procession to the execution site. This meant that when a penal surgeon checked for life-signs the condemned was fully clothed in a rough woollen garment from head to toe. Quickly stripping the body was essential before monitoring medical death since the shroud was covered in excrement, sweat and urine. Some prisoners had thus a 'good body (young and muscular)', whereas others were 'contaminated bodies (dirty and diseased)', with the majority in a 'bad shape (after hurried or mishandled executions)'.

At Nottingham on for example 17 April 1784 when two culprits called 'Henfrey and Rider' were hanged 'the executioner fixing the rope too far back on Henfrey's neck' had to ask the prisoners to assist him in getting the rope into the correct position. ${ }^{79}$ Newspaper reporters noticed that 'the caps provided' to cover their faces were 'too little'. Things were so badly run that 'Henfrey called on Rider to make a spring [escape]' because he thought they had a good chance of making a getaway. Ironically the act of pulling away on the misplaced rope actually tautened it around Henfrey's neck as he leapt forward and 'doing for himself at the same instant, by which he broke his neck and never stirred afterwards'. In a young and muscular man such a quick break left behind a 'good body' to be argued 
over because as a highwayman he did not automatically go for dissection but was a valuable research tool that might be an 'extra'. Rider meanwhile had lost faith that he would be killed efficiently. The local press noted that 'he asked a gentleman for his watch, to look at what o'clock it was' to count down his deadline. ${ }^{80}$ In such a state of heightened anxiety and fear his corpse was unsurprisingly in 'a bad condition' at the end.

Other bodies were handled much better like that of Anne Castledine on 17 March 1784 convicted of child murder. At a double-hanging she was executed with 'Robert Rushton the fellow murderer' and both were despatched with efficiency. Yet it was Anne's body that aroused intense medico-legal interest in the Midlands. The General Evening Post recorded that 'both bodies were 'taken to county hall in order to be publicly exposed and dissected'. ${ }^{81}$ Further source material uncovers however how gender dictated the precise medico-legal steps. Robert's body was muscular and therefore valuable. He was opened up to be anatomically checked and later dissected in Nottingham town. Anne's corpse was initially opened up with a 'crucial incision', the cross-like cut on her torso, to establish her medical death. Then it was 'exposed on boards and tressels [sic] in front of County Hall for two days' so that ordinary people could walk around it and see that a child killer was 'truly dead'. ${ }^{82}$ In the next chapter we will encounter this basic equipment in more detail. For now what is important to appreciate is that the table was mobile, it could be levered up and down to take in and out of County Hall each night, and had to be erected twice on two separate days to satisfy the large crowds filing past over a forty-eight hour period. Meantime there was considerable local discussion about where to dissect such a 'good body'. She was a fertile young woman and corpses like it attracted a lot of medical competition. In the end a decision was taken by a judge in consultation with the local medical fraternity to send her body to 'a surgeon in Derby'. Nearby, men like Erasmus Darwin were considered better qualified to make full use of such a valuable medical research opportunity (we will be revisiting the Derby medical scene in more detail in Chapter 4). The matter however did not rest there.

A lot of urban myths soon circulated about post-mortem 'harm' in controversial cases across the Midlands. The 'good body' might be morally contaminated but it was believed to have romantic connotations and material potency that endured 'in the name of Death'. Local gossip thus held that just before the Derby dissection of Anne Castledine got underway a 'strange gentleman took up the heart, kissed and shed tears upon it, 
squeezed a drop of blood on a handkerchief and rode off' ${ }^{83}$ Such was the power of the dissection story of this criminal corpse that almost a hundred years later local histories repeated the heartfelt tale verbatim. It is a keen reminder that bloodletting to check vitality was also bound up with popular notions of the wounded heart, being broken-hearted, and the heart as an emblem of the emotional centre of humanity. As Louisa Young in her recent reappraisal of the history of the heart reminds us: 'It is painful for the heart to be written on, engraved, branded: and painful to be opened up and read'; if moreover 'the heart is full of blood, then blood can be ink and the heart an inkwell ...from the 17th century heart-shaped inkwells abounded' in popular culture. ${ }^{84}$ The deterrence value of this type of heartnarrative is self-evident and was exploited by legal, medical and religious writers. Yet, the blood-stained handkerchief dipped in the heart-drops of a child murderess by a stranger, who may have loved and lost, also keyed into popular notions about the vital nature of bodies and their organs sent for criminal dissection. Surgeons had to work with such traditions or risk losing bodies altogether across the Midlands region.

Another set of executed bodies was far more troublesome because getting them undamaged was hazardous. On 10 August 1803 William Hill was hanged at Nottingham for the 'rape (attended with great brutality) of Mrs Sarah Justice, the wife of a respectable farmer at Bole, near Gainsborough'. Local newspapers reported that Hill had been brought up 'very imperfectly, - an associate of bad men, dissolute, and grossly licentious'. He confessed to the prison-clergyman that: 'He had made criminal attempts upon other females, one of whom was only 12 years of age, but without success'. Newspaper sources suggest that there was little local sympathy for such a violent character and few locals cared what happened to his body after being hanged. The Murder Act did not send convicted rapists to be dissected but few doubted that he deserved the harshest post-mortem sentence. Sentiments hardened when Hill tried to escape on the way to Gallows-hill. On the morning of the execution it took six men to get him out of his cell, he managed to leap from the cart transporting him, and the crowd was said to be in 'great astonishment and agitation'. In the end

Several of the Sheriff's men to hand immediately struck him with the blunt end of [their] javelins, and in spite of his horrid language and struggles, he was again forced to ascend the cart, and compelled to meet his fate. This hardened malefactor was about five feet eight inches high, and extremely robust and muscular. ${ }^{85}$ 
This was the sort of 'extra body' that surgeons hoped to get, but being bludgeoned before execution did damage the surface anatomy. So 'extras' tended to be about opportunity costs too. They often came with surprises as well. Thomas Dover who had been a physician in practice for fifty-eight years wrote in 1762 that he once found a large quantity of 'mercury... in the Perineum of a Subject I took from the Gallows for Dissection' which had 'rotten bones' caused by the poison that did not show up on the skin's surface before execution. ${ }^{86}$ This standard treatment for venereal disease made his contaminated body doubly dangerous in death. When indeed the executioner was really inept 'extras' often turned out to be 'lost causes'. This was the case on 16 August 1791 when John Milner was executed for 'cow stealing' and the local press reported:

He had hung a few seconds, when the knot of the rope gave way, and the wretched man fell heavily to the ground. Upon being raised, and the preparations for his suspension commencing afresh, he seemed painfully conscious of his situation and exclaimed "My God, this is hard work". Either from the inefficiency of the hangman, or some cause unexplained, several minutes elapsed ere the preliminaries were re-adjusted ; and it was not until a ropemaker named Godber pushed the blundering functionary aside, and tied the man up himself, that the cart was a second time driven away. The execrations of the spectators at the executioner were very loud and general. Milner was a native of Eakring, and was a very stout, broad-set man, nearly six feet in height. His body was buried the same day, in St-Mary's church yard. ${ }^{87}$

There was of course the option to disinter for 'extras' not covered by the Murder Act but again local surgeons knew that acting illegally was tricky. In the well-known case of Thomas Hallam a convicted thief sentenced to death in 1738 he was

Interred in the churchyard of St-Mary, Nottingham, and a surgeon of the town, anxious to possess the body for the purpose of dissection, engaged a man named Rolleston to clandestinely remove it, from its resting-place. Accordingly, Rolleston and a confederate disinterred the body the night after burial, and placing it in a sack, the former took it away on his back... the undertaking, thus far, was comparatively easy. But on passing along Stoney-street, Rolleston fancied he heard the dead man pant, and his terror was so great, that he gladly left hold of his burden, and with his assistant, ran as if for life. Becoming, however, somewhat reassured, they, after an interval, deliberated on the course best to be pursued. If they took poor Hammond to a surgeon, it was their conviction, uncharitable as it might 
seem that he would cut him up, dead or alive; and if he really should not be dead, it would be equally dangerous to leave him in the street as to take him away. They therefore took the corpse, and placed it in a barn of a field. It was found there in the morning by a woman who came to milk, and was subsequently reinterred by friends, at Sutton-in-Ashfield. ${ }^{88}$

The physical condition of the corpse-whether it was in a good or bad shape, contaminated or an extra-reflected a wide range of medical opportunism in Nottingham, across the Midlands and other English counties too. This seems to explain why it was that some engravings of the Murder Act became so infamous in contemporary culture. Behind the imagery is a disturbing set of surgical encounters that merit reconsideration too in the final section of this chapter.

\section{The Artful Caricature of the Criminal Corpse}

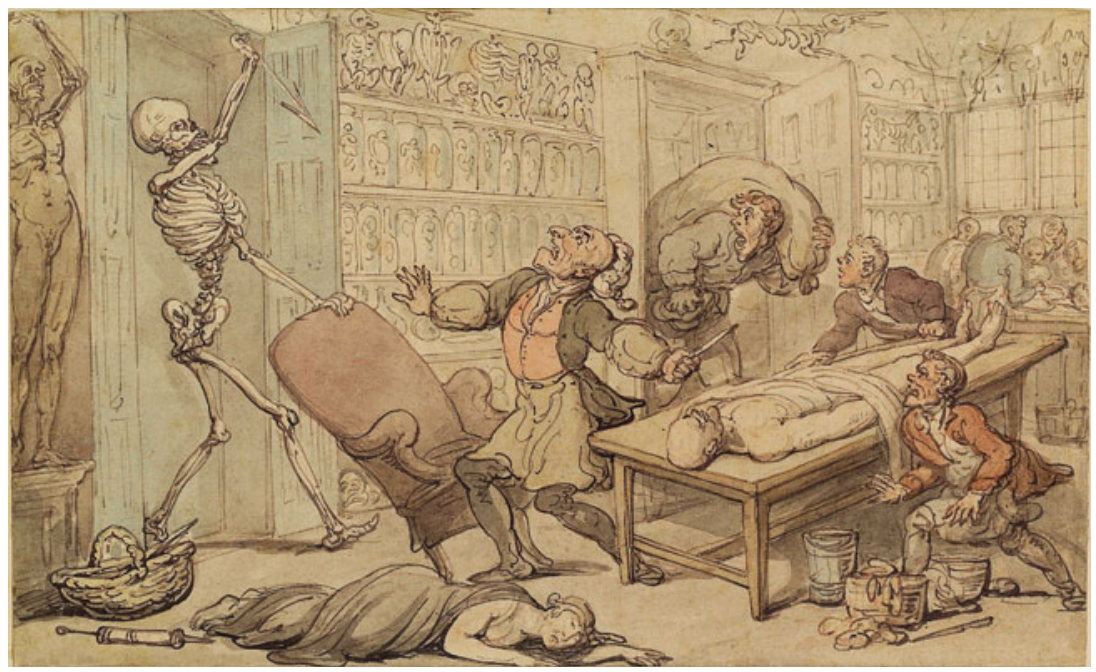

Illustration 3.1 (c) New York Public Library, Digital Collections, NYPL: bl6830809, taken from Spencer Collection, Spencer Coll. Eng. 1815-16, Thomas Rowlandson (1815), 'Death in the Dissection Room', original sketch published in 'The English Dance of Death'; from the designs by Thomas Rowlandson with metrical illustrations by J. Diggens published by R. Ackermann London 1814-16; Creative Commons Attribution-NonCommercial-ShareAlike 4.0 International License (CC BY-NC-SA 4.0) 
In 1815 Thomas Rowlandson produced a cartoon described in art history books as 'Death in the Dissection Room' (above Illustration 3.1). A central skeleton figure threatens with violence medical men and their resurrection-suppliers. It looks as though two anatomists and an assistant are about to dissect a cadaver, or does it ${ }^{89}$ Art historians have traditionally interpreted the giant skeleton to the left as Death (he is well over 6 foot in height). This angry and aggressive embodiment of the Grim Reaper seems to be seeking revenge on anatomists who have paid thieves to disturb graves for medical-profit. This book argues that a conventional reading of sack-men pillaging cemeteries is taken out of its medical history context. It is all too easy to read a picture caption, and look at what it says, rather than what is actually depicted.

Strictly-speaking the giant skeleton in the cartoon is not Death but Medical Death standing-by to kill a body on the dissection table: an important distinction. This is why the medical men and sack-men are caught by surprise. The skeleton pulls aside a large red chair (satirizing perhaps this most tradition symbol, a chair in medicine) to stop the anatomist cutting the corpse. Medical death has dominion here and he is poised to take the plunge. Notice for instance just how carefully Rowlandson has drawn the slanting perspective of the anatomist's knife. It is positioned in a diagonalline with medical death's fatal arrow. The effect is to create a viewing point that draws the audience's eye to the question of who has anatomical authority over 'absolute Death'. In this duel for medico-legal supremacy, the combat is not one the anatomist can win. What is needed is the presence of medical death in the room to proceed to dissection. Even though the lifeless looking body looks ready for a clean cut to the carotid artery in the neck, or along the chest cavity on the pencil-line of the breast-bone, it is self-evidently not 'truly dead'. Medical death is roused because the pale cadaver has vitality that is still in his purview. This general subtext is repeated in the placement of the objects on the floor where there is a basket of medical tools and a syringe to the side. These had two functional uses: to first inject hot water into the vital organs to test for vitality and then to squeeze wax into the body to preserve any tissue for anatomical specimen-taking. Looking more closely at the cadaver laid out is informative about body conditions in the room.

This is a body that has been cleaned up because it is unblemished and bloodless, a spectre of a human being but one still identifiable to the 
crowd: a crucial distinction. It has been shaved, is hairless, naked, and seems to have been washed down with camphor by the anatomist's assistant-notice his foot in the bucket, water spilling out, normally used to clean and then swill down the corpse. The skin is very pale and therefore drained of blood in the epidermis. So the person appears to be according to eighteenth-century sensibilities on the boundaries of life and death in the worst state of all 'the Name of Death'. It is very difficult to decipher whether there is any indication of a rope mark around the neck, but it is a tall man of considerable stature, partially draped with a cotton windingsheet. If he has been dug up then he is remarkably unsullied by the wooden spade, the strong pull of the grave-robbers out of the top of the coffin, and there is no sign of any bruising, mud-stains or straw-marks, on his exposed flesh from the exhumation. The winding sheet looks skimpy emphasizing that he may have been a poor man, his family unable to afford a secure burial, or a criminal cut down from the gallows not yet prepared for burial since he must undergo post-mortem punishment. Whatever his supplysource although he is lying in a dissection room, no anatomical cuts have been made as yet to his torso. We are seeing what the crowd would have looked at as they accompanied the 'good body' on the punishment journey of the condemned.

Perhaps the most intriguing thing about the image is the lack of a response in the medical-men huddled around another body in the background. Self-evidently medical death has no dominion in that part of the picture because a dissection and dismemberment is already underway on someone in 'absolute Death'. Nor does the skeleton figure of medical death threaten the woman lying-down on the floor in the foreground. She is a curious figure and to modern eyes looks superfluous and somewhat melodramatic. She cannot be dead since her limbs are not in rigor mortis. There is fluidity in her bodily expression. Her artistic placement seems therefore to have an experiential purpose. She has fainted just as the body is about to be cut open. Maybe she was the type of female that was often mentioned in newspaper reports who were enticed to the dissection room by the spectacle of an alpha-male, dangerous and damned. In this scenario, the reality of seeing a dissection was a fainting prospect. Another possibility is that in private medical museums along Fleet Street women were sometimes trained to prepare specimens and act as a guide to anatomical collections. ${ }^{90}$ Rowlandson seems to be mocking 
the weaker sex whose desire to be involved with notorious criminals had a material downside at criminal dissections: a theme we will be returning to in Chapter 6 when we consider how difficult it was to endure a full-scale dissection. There are of course many ways to read satire, but the balance of the visual and medical evidence surrounding the image suggests that the criminal corpse was a complex medico-legal commodity when it came into the dissection venue. It is important not to overinterpret visual sources since they often contain a certain artistic integrity that we may never grasp or which we have to learn more about since Rowlandson drew for private and popular consumption. Yet images like this also command our historical attention by encouraging us to look afresh at the complexity of medical death, anatomy and dissection, especially when we consider that this interior scene is basically what many provincial anatomy spaces looked like after the Murder Act (see Part II). They also alert us to lots of ambiguities and contradictions stimulated by the Bloody Code. Of these, the basic condition of corpses was subject to medico-legal modifications and new anatomical thinking over time. Those trends bring us to the famous images drawn by William Hogarth of criminal dissections and what they reveal about bodies being punished in the presence of the crowd.

In the history of eighteenth-century crime, Hogarth's four engravings The Four Stages of Cruelty (1751) are iconic. The final image in the series depicts a criminal archetype called Tom Nero who has been tried and found guilty of murder. He is about to meet the Reward of Cruelty by being dissected in an anatomical theatre. The engraving anticipated the Murder Act (1752) by twelve months. It depicted Tom's corpse opened by surgeons and about to be hauled up high on a pulley so his skeleton can be seen by those assembled under the auspices of a leading professor from the Royal College of Physicians. Looking anew at this symbolic representation from the perspective of the archival material presented thus far in this book, there are three things that are striking (see Illustration 3.2 below). 


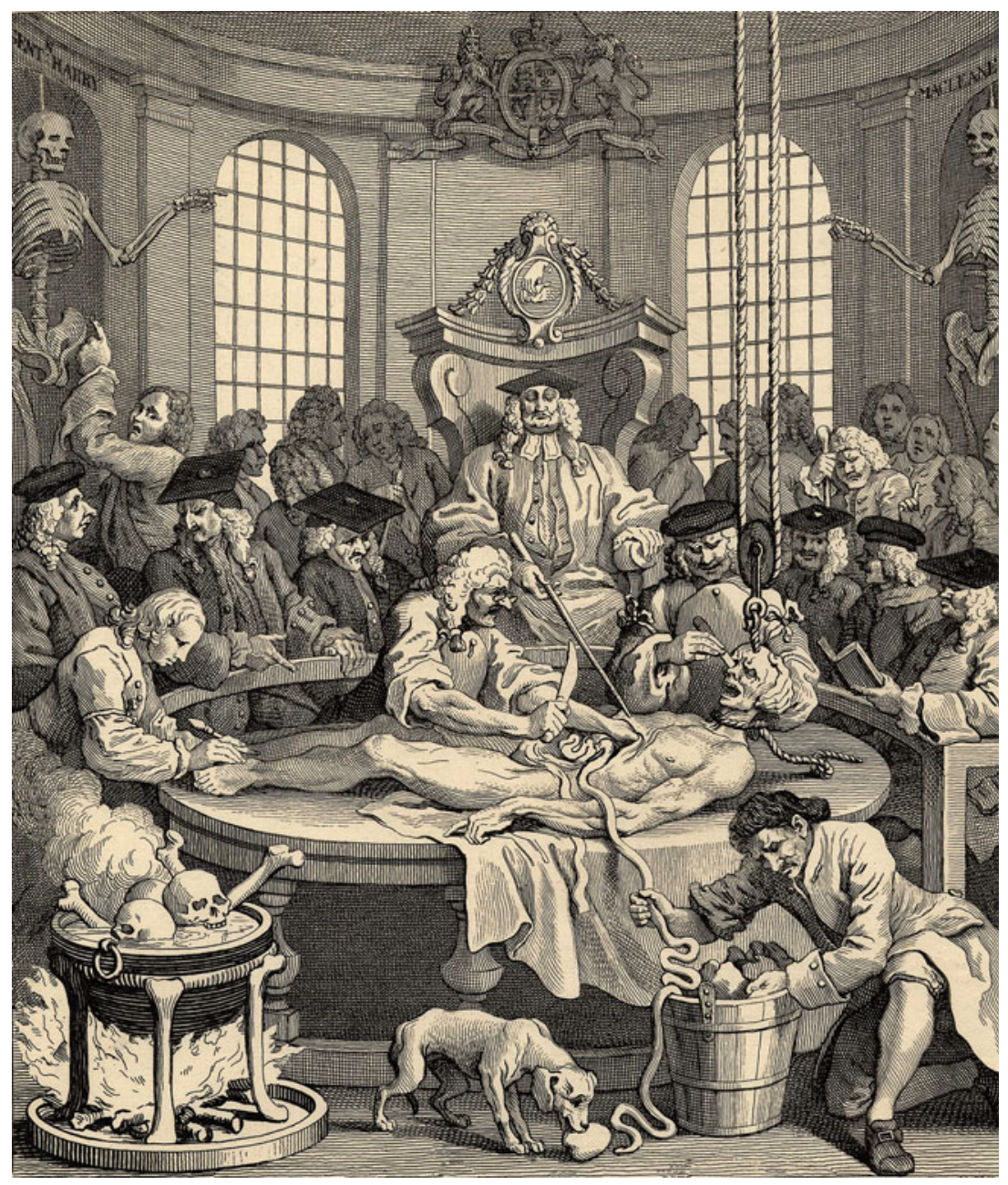

Illustration 3.2 C Trustees of the British Museum, William Hogarth (1751), 'The Reward of Cruelty', Image Reference, S, 2. 126, Digital Image Number ANl6677001, original engraving; Creative Commons AttributionNonCommercial-ShareAlike 4.0 International License (CC BY-NC-SA 4.0) 
The first is that this is arguably one of the most disturbing images of the eighteenth-century capital code because Tom Nero looks more alive than dead. Vic Gatrell first commented on the emotional appeal of the pained face. It is difficult to avoid the twisted visage that seems to express genuine feeling. The pincers on his nose are props for Hogarth's satirical angle that maybe Nero can smell his own body stink. Can he experience being in a bad shape, a contaminated state, with a muscular frame that is a medical prize? There is an unmistakable human impulse that pain however justified can be filled with pathos too. A second observation is that those surrounding the corpse do not flinch in the face of this pain and this is normal. This is the price of murder and the upside of medical advancement; or is it? These medical men according to the Hippocratic Oath are healers. Here they have become agents of a criminal justice system that involves them in taking life. Again, Hogarth's satire is bitter tasting. Tom Nero's story is about a cruel society that has bred a cruel boy who embraced cruel criminality and meets a cruel end-even so, it would be cruel indeed if the anti-hero had not yet reached medical death! Either Hogarth exploited his artistic license to dramatize the scene's medical melodrama to increase sales of his engraving or he had seen from his visits to St Bartholomew's Hospital dissection rooms that not everyone died on the gallows. ${ }^{91}$ It is important to be alert to such alternative readings because in many respects the image is so familiar that it has become almost an art historical cliché.

Another, third, striking feature in the engraving is that the image made sense to those at the time: a point Vic Gatrell first made. Hogarth seems to be encouraging the viewer to see the rule of law as contradictory and contrived. At the heart of the Reward of Cruelty are shifting concepts of medical authority that are powerfully in transition, just as the criminal body is a powerful instable metaphor being deployed by the State. It's medicolegal character will go on being modified for the next thirty years and so an image that looks finished is actually about to be continually refashioned. It resonates powerfully to viewers because the engraving was produced when the Murder Act was imminent but still lacked legal bite (unlike the dog eating the intestine sausages!). Hogarth knew broadly what the new capital punishment entailed and he was familiar with dissection sessions, but only after 1752 were these brought together for wider public consumption. So this image is a modified version of an artistic vision of what is coming into force. The crowd are outsiders, but within a year they will be insiders, seldom excluded from the post-mortem rites. The terms of the new legislation's authority are therefore still being refined, reworked and reviewed. The deliberate headcount of 21 medical men given a privileged access hints 
at this instability since the post-mortem punishment peopled by medical actors is fluid. Historical sources confirm that the physicians, surgeons, and barbers who look united in the image were the opposite. Their authority was a divisive one and could be acrimonious. It is notable that modified reforms would result in the barbers and surgeons splitting: the latter forming the Company of Surgeons in 1745, later awarded a Royal Charter by 1800 . They would change premises too: the surgeons moving from the Old Bailey to Lincoln's Inn Fields in Holborn by 1797. So Hogarth's chosen medical space, its staging, the predicted audience, and the medico-legal scenery, are under constant negotiation because of the multiplicity of meanings attached to the central figure of the criminal corpse, and medically-speaking, he is not a corpse, but peri-mortem. The image is a performance of a large-scale drama and this is Act One. The 'bad shape' of the main character promises lots of scene-changing, Tom Nero arrests attention because what cannot be denied is that his body is in a pained condition and he is a medico-legal creation. Ironically this revitalises his disempowered corpse as life ebbs from his body: the reverse effect to the official one intended.

We end this brief discussion on the condition of criminal corpses at a theatrical time in imaging-making. The Drury Lane Journal featured this artistic trend on 20 February 1786. A satirical play had just opened called 'Punishment of Felonies, Burglaries and the like'. In advance of opening night a poster invited theatre-goers to read a synopsis of its script. The contemporary mockery was evident for the extension of even harsher capital legislation:

\section{SCHEME}

FIRST, That one or more surgeons be appointed for every jail, to make ottomies [anatomies] of all the condemn'd bodies.

SECOND, That all the malefactors, within two days after the death sentence is pass'd upon them, be cut up alive in the prison yard; and that every one confin'd there for capital offences be oblig'd to stand by and see it done.

THIRD, That, while they are thus ottomising [anatomising] they be tyed hand and foot to prevent their struggling and that their mouths be gagg'd, to hinder their horrible shrieking and groans. ${ }^{92}$

If, as the satire of Rowlandson, Hogarth, and their circle of artists that attended criminal dissections seems to suggest in their image-making, the melodrama of human vivisection had a strong basis in medical reality, then their artistic integrity deserves better recognition by criminal historians. 
The crowd that gathered round the corpse in a 'bad condition' came to know its medical potency in the dissection and playhouse theatres of Georgian England.

\section{Conclusion}

Penal surgeons had to exploit those opportunity costs that came within the scope of a working-choreography of punishment rites at the gallows. They tried to assert their medical prerogative when the condemned became perimortem. It was essential that those convicted to die were handed-on with as little damage as possible from the execution process nevertheless the material condition of the human material was inconsistent. Surgeons could try to intervene to speed things up but this was often decided by two local factors. If there was a lot of 'natural curiosity' about the condemned, then it was better to stand back and wait to be called forward by the hangman. On other occasions it was possible to be more assertive when resentment against the convicted was intense in the vicinity of a violent homicide. The varying nature of the emotional engagement and the changing tempo of the penal rites meant that the peri-mortem stage was a medical dance. It had to be estimated strategically from a material and metabolic standpoint. ${ }^{93}$ This was then a liminal penal space filled with synaesthesia and of stimulating emotives. These aroused the archaeology of emotional expressions the early modern crowd had an opportunity to give voice to, in the sorts of ways that William Reddy has envisaged (introduced in Chapter 1). ${ }^{94}$ Although it has not been possible to hear every conversation in oral cultures at this historical distance, the fact that a lot of conversing was going on was however a consistent feature of the average penal surgeon's working-life: a theme Chapter 6 returns to. The actual bodies about to be punished smelled foul and were hard to handle. They slipped and slid through surgical fingers, wet with urine, faeces, semen, blood and sweat. Even experienced medical men like those of the famous Hey family of surgeons in Leeds admitted privately that: 'No stink can compare to a body stink'. Strong prisoners capable of strangling murder victims with their bare hands had powerful willpowers to survive. They also had muscular bull-necks that did not break on the rope. Their shaven heads and tattooed torsos made them in visual terms striking physically from head to toe. This made them mightily attractive and pungently repellent. Most spectators therefore experienced mixed-emotions about peri-mortem bodies and surgeons navigated that spectrum in situ.

On being cut down from the gallows some convicted murderers were strictly speaking still the 'dangerous dead'. Potentially many threatened 
the public good of the local community by being contaminated by common diseases like head lice, dangerous summer fevers, and life-threatening conditions such as dysentery of the bowls. Lying on the floor or on the dissection table some were pock-marked by smallpox. A nick of the dissector's knife was a well-known health risk to the penal surgeon on duty (see Chapters 5 and 6 for more details). Bad blood could then literally blood-poison the post-execution rituals. Against this hazardous backdrop it is striking how many ordinary people wanted to be in close proximity to the criminal corpse oozing body fluids and spirited danger. That outcome expresses the disturbingly powerful nature of the post-execution punishment rites for many ordinary early modern people. Trial narratives suggest that the five senses of each spectator were arrested as they jostled to get a good view of the body laid out for their inspection; and this, regardless of the scale of underlying emotions, whether apathetic, mildly interested, or thrill-seeking. Above all, it was the condition of the criminal corpse that shaped what was about to happen next after the gallows. Neglecting to trace the onwards passage of the body through the punishment process is therefore a significant historical omission in eighteenth-century studies.

A wide variety of contemporary sources suggest that the power of the criminal corpse was mutable and pluralistic. It was the subject of a sort of 'cultural compost'. ${ }^{55}$ The body degraded physically in the dissection venue but the processes of disintegration and their timings had a powerful symbolism too. The pre and post-executed body naturally worked intandem and had a medical symbiosis that has been neglected. This explains why anatomization was about multi-tasking: to check lifelessness, manage rigor mortis and slow down 'harm' done on the gallows. It got the condemned into a medical sphere of discretionary justice before putrefaction speeded up. Artists like Thomas Rowlandson and William Hogarth consequently saw the criminal corpse as a compelling subject for satire. The challenge for historians is to look anew at what their artistry reveals about a cross-section of public opinion. It was not obvious or inevitable that penal surgeons would open the corpse cleanly. They could be caught in a medico-legal duel for the condemned in the cartoons of Rowlandson. Often they were depicted in an unedifying ethical situation surrounding human vivisection illustrated by Hogarth. In turn, both anatomical trends were mocked in melodramas on the London stage. Enacting the Murder Act was never easy, nor palatable, to early modern sensibilities confronted with different types of medical opportunism. Spectators might relish an execution but be unable to stomach its aftermath however much they were determined to do so. Even the most blood-thirsty found it hard to 
bear the olfactory showcase. A worrying logistical problem was how to manage the types of unsavoury anatomical information (like spontaneous menstruation and ejaculation) that came into the public domain from those that crowded round the criminal corpse. Copy-cat killings were likewise unnerving for a legal fraternity charged with maintaining public safety. In notorious cases, dangerous criminals did use execution methods and dissection techniques in circulation to murder their victims. Opening up the criminal justice system to try to increase the deterrence value of capital punishment had therefore a troubling downside. To get closer to the dilemmas contemporaries encountered, Part II of this book now journeys onwards with the criminal corpse that captured widespread 'public curiosity' in English provincial life.

\section{Notes}

1. V. A. C. Gatrell (1994) The Hanging Tree: Execution and the English People, 1770-1868 (Oxford: Oxford University Press).

2. Ibid., p. 29.

3. Gatrell, The Hanging Tree, p. 46.

4. On the longevity of medical definitions, see, Arthur S. P. Jansen, Xay Van Nguyen,Vladimir Karpitskiy, Thomas C. Mettenleiter, and Arthur D. Loewy (1995), 'Central Command Neurons of the Sympathetic Nervous System: Basis of the Fight-or-Flight Response', Science, Oct. Vol. $27,644-6$.

5. The autonomic nervous system (ANS) comprises two branches: the sympathetic nervous system (SNS) and the parasympathetic nervous system (PSNS). The SNS is the "fight or flight" system, while the PSNS controls heart rate, reflex actions, and brain input. The SNS is a quick response system that mobilizes the body into action whereas the PSNS slows down strong physical reactions for emotional well-being: the two branches work by balancing each other under normal conditions, but tend to act independently in response to fear and trauma.

6. Paul Barber (1998), Vampires, Burial and Death: Folklore and Reality (New Haven: Yale), p. 119.

7. See, M. M. Shoia, B. Benninger, P. Aqutter, M. Loukas, and R. S. Tubbs (2013), 'A Historical Perspective: Infection from Cadaveric Dissection from the Eighteenth to Twentieth Centuries', Clinical Anatomy, Vol. 26, II, 154-60.

8. Some historical demographers have seen the long eighteenth-century as an age when the triage of social cleansing typified English society, see, for instance, Richard L. Rubenstein (1983), The Age of Triage: Fear and Hope in an OverCrowded World, (Michigan, USA: Beacon Press, University of Michigan). 
9. 'Extras' were those hanged for a lesser capital offence like highway robbery. Some sold their body before death to pay for a good send-off, or their family were paid to supply the surgeons.

10. Chester Annual Register, (Chester, 1771), entry 7 September, execution of John Chapman.

11. Ibid.

12. J. Lawrence (1983), The History of Capital Punishment (London: Citadel Press), pp. $44-8$.

13. Simon Devereaux (2009), 'Recasting the Theatre of Execution: the Abolition of the Tyburn Ritual', Past and Present, Vol. 202, 127-74, argues that this increased the 'theatrics of the execution' staging and processes.

14. Gatrell, The Hanging Tree, p. 54.

15. Physical details are outlined in, A. Koestler and C. H. Rolph, (1961, lst edition) Hanged by the Neck (London: Penguin) and Dr Harold Hillman, Guardian newspaper, 15 December 1990, both discussed in Gatrell, The Hanging Tree, p. 45, endnote 54.

16. Thomas Stuttaford, "Swift end rests with skill of the hangman," Times newspaper online, (1 January, 2007), http://www.timesonline.co.uk/ article $/ 0,3-2526006,00$. html.

17. Robert Hutchinson (2007), Thomas Cromwell: The Rise and Fall of Henry VIII's Most Notorious Minister (London: Weidendfeld and Nicholson), p. 64, explains that Cromwell was in charge of the first executions of the Reformation under Henry VIII. It was he who permitted using a dagger or sword to cut the head off the criminal body whilst it was still jerking on the rope, which the Murder Act repealed.

18. Chester Annual Register, (Chester and London: Baldwin, Craddick and Joy, 1771), entry 7 September, execution of John Chapman.

19. On Leicester executions, see, Alfred Temple Patterson (1954), Radical Leicester: A History of Leicester, 1780-1850 (Michigan: University of Michigan Press), p. 160.

20. On eighteenth-century capital punishment timings and their disputes, see, Jerry White (2013), A Great and Monstrous Thing: London in the Eighteenth Century, (London: Random).

21. London Magazine, (April 1733), pp. 213-3.

22. Historical Chronicle, Gentleman's Magazine, Volume 6, (September, 1736), p. 549.

23. See, list of eighteenth-century sources cited in Notes and Queries (JanuaryJune, 1861), 2nd series, Volume II, p. 314.

24. Refer endnote 1.

25. This Biblical phrase is attributed to the English evangelical preacher and martyr, John Bradford (1510-55). He is quoted as saying, 'There but for the grace of God, goes John Bradford', when witnessing criminals being led to the scaffold. Later he was burned at the stake in 1555 and went to the gallows 
pronouncing, 'We shall have a merry supper with the Lord this night'. The sentiment inspired early modern Christians, like, Edward Bickersteth (1822) A Treatise on Prayer (London: private publication), p. 60.

26. Peter King (2000) Crime, Justice and Discretion in England, 1740-1820, (Oxford: Oxford UP, 2000), p. 1.

27. Ibid.

28. Mary Shelley (2003 edition), Two Works by Mary Shelley (London: Peverell Press), chapter 21, Frankenstein.

29. He was the nephew of William Hey senior, a leading Leeds surgeon, who received gallows bodies in the city.

30. Leeds University Special Collections, MS/1990/5, Hey Family Correspondence, 1828-42, Samuel Hey wrote to his elder brother William at St John's College Cambridge about his medical training experiences.

31. I am grateful to Dr Richard Ward for altering me to the fact that William Hey senior also discussed his preference for bodies in winter and spring rather than summer; see, Richard Ward (2015), 'Wilberforce, Anatomists, and the Criminal Corpse: Parliamentary Attempts to Extend the Dissection of Offenders in Late Eighteenth-Century England', Journal of British Studies, January, Volume 54, Issue 1, 63-87; copy available at Leicester University, pp. 1-28, quote at p. 12, taken from Spencer-Stanhope MSS, SpSt $/ 11 / 5 / 1 / 2$, WYAS.

32. Andrew Knapp and William Baldwin eds (1828) The Newgate Calendar, 1824-8 (London: J Robin and Co), 'Case of William Proudlove and George Glover executed at Chester, 28 May, 1809, for salt-stealing, after a First Attempt to hang them had Failed' e-transcript available at http:// www.exclassics.com/newgate/ng502.htm.

33. 'Remarkable Domestic Events: Fortitude', The Historical Magazine, (April, 1789), p. 271.

34. These attributes are now well established, as a result, in crime histories, see, for a recent example, Richard M. Ward (2014), Print Culture, Crime and Justice in Eighteenth-Century London (London: Bloomsbury).

35. See, historic-standing in, Carol Heron, John Hunter, Geoffrey Knupfer, Antony Martin, and Charlotte Roberts (1995), Studies in Crime: An introduction to Forensic Archaeology (London and New York: Routledge).

36. Refer, James Copland (1833), A Dictionary of Practical Medicine, Vols. 1-3 (London: Messrs Longman).

37. This is often noted in diaries about hospice care or dying at home. Hon. Jane Clark, wife of Alan Clark MP for instance records that Alan's dead body laid out for burial in their bedroom was 'I must say, had made our room a tiny bit high, and the window had to be shut because of the flies' in late-summer, A Clark, transcribed and edited by Ion Trewin (2002), The Last Diaries: In and Out of the Wilderness: Alan Clark Diaries, Volume 3, (London: Phoenix Press) entry Monday 6 September 1999, p. 491. 
38. Refer, for example, W. Lambert, medical commentator (1831), 'Letter to Lancet: Effects of Hanging Upon the Organs of Secretions \& so on', Lancet dated 14 Sept., published in the Sept. edition, p. 808, stated that: 'penal erection of the male sex by the infliction of death by hanging, [it] is a well-established fact'.

39. See, Edward H Campbell, Surgeon, Royal Navy (1831), 'Letter to Lancet: Occurrence of Menstruation during Hanging', Lancet, letter dated 20 August 1831 but published in the Sept. edition, p. 704 and discussion with its taboo nature in Charles Cooke, Surgeon, Holloway Prison (1831), 'Letter to Lancet: Occurrence of Menstruation during Hanging', Lancet, letter dated 1 September, published in the Sept. edition, pp. 751-2.

40. Refer, Rick Harrington (2013), Stress, Health and Well-being: Thriving in the Twenty-First Century (Belmont, USA: Wadsworth Publishers), p. 83.

41. A general point made by Barber, Vampires, Burial and Death, p, 105 but seldom with regard to criminal dissections.

42. Refer, John M. Beattie (2001), Policing and Punishment in London, 1660-1750: Urban Crime and the Limits of Terror Part II, (Oxford: Oxford University Press).

43. Normal life expectancy was around forty-eight years old over the course of this book's chronological focus.

44. E T Hurren (2011), Dying for Victorian Medicine: English Anatomy and its Trade in the Dead Poor, 1832 to 1929, (Basingstoke, Palgrave), chapter 3 , details the nineteenth-century use of water baths for body preservation.

45. Barber, Vampires, Burial and Death, p. 110.

46. See, Colin Jones (2014), The Smile Revolution in Eighteenth-Century Paris (Oxford: Oxford University Press).

47. See, notably, David Garland (2011) 'Modes of Capital Punishment: The Death Penalty in Historical Perspective', in David Garland, Randy McGowan and Michael Meranze eds. America's Death Penalty: Past and Present (New York: New York University Press), chapter 2, pp. 30-71, quote at p. 42.

48. Stuart Banner (2003), The Death Penalty: An American History (New Haven: Harvard University Press), chapter 3, 'Degrees of Death' pp. 33-87, quotation at p. 70 and endnote 33 citing original English sources.

49. Thomas Laqueur (2011), 'The Deep Time of the Dead', Social Research, Vol. Fall, III, 799-820, quote at p. 802 .

50. Ibid., p. 805 .

51. Esther Cohen (1989), 'Symbols of Culpability and the Universal Language of Justice: The Rituals of Public Execution in Late Medieval Europe', History of European Ideas, Vol. 11, I-VI, 407-16 quote at p. 410. 
52. John William Holloway (1831), An Authentic and Faithful History of the Atrocious Murder of Celia Holloway, (London: W. Clowes and Son Ltd), p. 235.

53. Ibid., p. 237.

54. Evidence compiled from contemporary reports in the 'Confession of Holloway', The Observer, 22 August 1831, and Brighton Herald, 20 August 1831 .

55. In court John defended that his lover was innocent and the constables failed to find enough reliable evidence to convict Ann Kennet as his accomplice. She was subsequently released and disappeared from the local area.

56. Holloway, An Authentic and Faithful History, p. 269.

57. Ibid., pp. 287-88.

58. Holloway, An Authentic and Faithful History p. 291.

59. Ibid, p. 291.

60. Holloway, An Authentic and Faithful History p. 292.

61. F. and K. Wood eds (1992), A Lancashire Gentleman: The Letters and Journals of Richard Hodgkinson, 1763-1847 (Dover: Alan Sutton Press). p. 50 .

62. I am grateful for an advance copy of Shane McCorrestine (2015), William Corder and the Red Barn Murder: Journeys of the Criminal Body (Basingstoke: Palgrave Pivot).

63. Albert Manns (2012), 'Shorn Scalps and Perceptions of Male Dominance', Social Psychology and Personality Science, July, VII, p. 1, led to him concluding that 'men experiencing natural hair loss, may improve their interpersonal standing by shaving [more]'.

64. A gender theme explored by social scientists like Richard Collier (1998), Masculinities, Crime, and Criminology: Corporeality and Criminal(ised), (London: Sage Publications).

65. It was a small town in Surrey, 30 miles south of central London.

66. 'Report and Trial of Chennel and Chalcraft', The Observer, 16 August 1818, pp. 1-14, quotes at p. 1.

67. Ibid, p. 2.

68. 'Report and Trial of Chennel and Chalcraft', p. 2.

69. Ibid. p. 3.

70. 'Report and Trial of Chennel and Chalcraft', quotes at p. 1.

71. Ibid., pp. 13-14.

72. Reconstructed from record linkage work on court records in, Andrew Knapp and William Baldwin eds (1828) The Newgate Calendar, 1824-8 (London: J Robin and Co); 'GEORGE CHENNELAND J. CHALCRAFT, Executed August, 1818 for the atrocious murder of Chennel's father and his Housekeeper, at Godalming,' e-transcript available on http://www.exclassics.com/newgate/ng577.htm; and detailed contemporary newspaper reports in The Examiner, No 555 (16 August 1818), p. 519; Leicester 
Journal and Midlands County Advertiser, Volume LXVII (21 August 1818), Issue 3346, pp. 1-4; Edinburgh Advertiser, (21 August 1818), p. 4.

73. See, The Observer, 16 August 1818 and a subsequent 'Report of the Trial of Chennell and Chalcraft' published as a pamphlet by Duncombe, 19 Little Queen Street, Holborn, 1818.

74. Morton D. Paley (1996), Coleridge's Later Poetry, (Oxford: Clarendon Press), p. 56 points out that there was a strong eighteenth-century connection between the word 'jail' and the concept of 'Limbo' for sinful souls.

75. He carried out 44 hangings in the East Midlands and seems to have been responsible for another 22 elsewhere, totalling 66 between 1820 and 1847. When he died aged 70 the Law Times and Journal of Property, (1848) Vol. 10, p. 510, said his eldest son was to succeed him as hangman.

76. Ron Knight (2009), Murder in the Shambles, (Milton Keynes: Author House UK Ltd), pp. 83-6, quote at p. 86.

77. Anon (1827), The Strangers Guide through the town of Nottingham being a description of the principle buildings and objects of curiosity in the ancient town (Nottingham: Sutton and Sons), relevant entries can be accessed online at http://www.nottshistory.org.uk/books/nottinghaml827/ guide6.htm.

78. These are recorded widely in local histories like John Potter Briscoe (1895), The Old Guild Hall and Prison of Nottingham (Nottingham: Sutton and Sons); James Granger (1907), 'The Old Streets of Nottingham', Transactions of the Thornton Society, Volumes III and IV, 3 and 7 February issues.

79. 'Nottingham executions', Felix Farley's Bristol Journal, 17 April 1784, Issue $1851, \mathrm{p} .1$.

80. Ibid., p. 1.

81. 'Nottingham executions', General Evening Post, 23 March $1784-25$ March 1784, Issue 7813, p. 2.

82. William Stevenson [of Hull] (1893), Bygone Nottinghamshire (Nottingham: Hard Press Publishing), p. 183.

83. James Orange (1840), History and antiquities of Nottingham, (Nottingham: Nabu Press), p. 447.

84. Louise Young (2002), The Book of the Heart (New York: Doubleday, Random Books), p. 225.

85. See, http://nottinghamhiddenhistoryteam.wordpress.com/page/11/for contemporary records access.

86. Thomas Dover (1762 edition), The ancient physician's legacy to his country. Being what he collected himself in fifty-eight years of practice, and so on (London: H. Kent, for C. Hitch; J. Brotherton; and R. Minors), p. 84. 
87. See, http://nottinghamhiddenhistoryteam.wordpress.com/page/11/for contemporary records access.

88. Ibid., p. 11 .

89. Image depicted at http://www.18thconnect.org/news/?p=80yet.

90. Matthew Craske (2011), 'Unwholesome' and 'pornographic': A reassessment of the place of Rackstrow's Museum in the story of eighteenthcentury anatomical collection and exhibition', Journal of the History of Collections, Vol. 23, I, 75-99.

91. It has recently been established that the dissection might have taken place at St Bartholomew's Hospital, where all three identifiable surgeons in the image were based. It does however also feature the Cutlerian Theatre of the Royal College of Physicians, near Newgate. The throne is the same and bears their arms; and its curved wall did resemble a cockpit. The niches of the Barber-Surgeons' Hall were not used for dissection displays of skeletons until after the surgeons split away to form the Company of Surgeons in 1745. On the context, refer, Ronald Paulson (1992), Hogarth, (London: James Clarke \& Co), p. 35.

92. 'Punishment of Felonies, Burglaries and the Like', Drury Lane Journal, 20 February 1786.

93. Building on the approach of, Fay Bound Alberti (2009), 'Bodies, Hearts and Minds: Why the History of Emotions Matters to Historians of Science and Medicine', Isis (Chicago Journals, The History of Science Society), Vol. 100, Dec. IV, 798-810.

94. See, notably, William Reddy (1997), 'Against Constructionism: The Historical Ethnography of Emotions', Current Anthropology, Vol. 38, 327-51.

95. I owe this apt phrasing to A. Nicolson, (2011), The Gentry: Stories of the English (London: Harper Press).

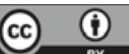

This chapter is distributed under the terms of the Creative Commons Attribution 4.0 International License (http://creativecommons.org/licenses/by/4.0/), which permits use, duplication, adaptation, distribution and reproduction in any medium or format, as long as you give appropriate credit to the original author(s) and the source, provide a link to the Creative Commons license and indicate if changes were made.

The images or other third party material in this book are included in the work's Creative Commons license, unless indicated otherwise in the credit line; if such material is not included in the work's Creative Commons license and the respective action is not permitted by statutory regulation, users will need to obtain permission from the license holder to duplicate, adapt or reproduce the material. 